\title{
Entrepreneurship and Information on Past Failures: A Natural Experiment
}

\author{
Christophe Cahn ${ }^{1}$, Mattia Girotti ${ }^{2}$ \& \\ Augustin Landier ${ }^{3}$
}

\author{
September 2017, WP \#644
}

\begin{abstract}
We analyze how public information on past entrepreneurial failure affects entrepreneurs' ability to borrow. We exploit a policy shock from 2013 in France, which eliminated a highly salient public reporting to banks of managers involved in non-fraudulent corporate liquidations. We find that the flag removal makes failed entrepreneurs significantly more likely to restart a business or to borrow from a surviving business, despite the fact that bankers can find the failure information from other public sources for a small cost. Restarters create companies that have a higher probability of default.
\end{abstract}

Keywords: Entrepreneurship, Access to credit, Bankruptcy.

JEL classification: G33, L26.

\footnotetext{
${ }^{1}$ Banque de France; christophe.cahn@,banque-france.fr; 31 rue Croix des Petits Champs - 75049, Paris CEDEX 01, France.

2 Banque de France; mattia.girotti@banque-france.fr; 31 rue Croix des Petits Champs - 75049, Paris CEDEX 01, France.

3 Toulouse School of Economics; augustin.landier@tse-fr.eu; 21 Allée de Brienne - 31000, Toulouse, France.
} 


\section{NON-TECHNICAL SUMMARY}

In this paper, we analyze the causal impact of public information regarding past corporate defaults on entrepreneurs' access to credit and ability to create a new firm. We find that the flagging of past failures causally impacts 1) the restart probability of failed entrepreneurs, 2) the new corporate loans contracted by flagged entrepreneurs, and 3) the interest rate at which they borrow.

To establish the link between information on past failure and entrepreneurship, we exploit a natural experiment from France. Before 2013, Banque de France produced a highly visible record of past corporate bankruptcy for firm managers. Such individual flagging was lasting for exactly three years and was made available to banks via Banque de France's FIBEN database, a widely used scoring system of firms and managers. A 2013 reform suppressed the publication of this flag in the FIBEN data for individuals involved in one bankruptcy only. As a result, more than 140,000 individuals were simultaneously deflagged and informed about it.

Our empirical strategy consists in comparing the dynamics of the entrepreneurs whose flag lasted three-years (i.e., those whose flag removal arrived before the policy change) with the one of the entrepreneurs whose flag lasted less because of the policy change. Once the business cycle and other aggregate characteristics are controlled for, the only difference between those two groups of managers is the duration of the flag. Thus, by looking at what happens when the flag is removed, we can derive what is the effect of the information on past failures on entrepreneurs' ability to start a business and access to credit.

The following figure plots the dynamics of the probability of starting a business for failed entrepreneurs around the moment they are assigned the flag and the moment their flag is removed. There are three groups of flagged managers: 1) three-year flagged managers, 2) policy-affected managers whose flags last one year, and 3) policy-affected managers whose flags last two years. The first vertical line indicates the assignment of the flag, while the other vertical lines indicate flag removal, which changes depending on the group of managers considered. Comparing the pattern of restart of the policy-affected groups to the one of the pre-reform group (solid line) as a function of the time since flag start, it appears very clearly that the early removal of the flag causes a rise in restarts. In turn, this suggests that as soon as failure information is not immediately visible to bankers, failed entrepreneurs restart more easily.

We also analyze the impact of information on past failures through the prism of entrepreneurs managing multiple companies: After one of the companies fails, the other companies suffer from the entrepreneur's stigma on the credit market. We show that after removal of the failure flag, these companies borrow significantly more. This effect is particularly strong in industries where individual talent matters most.

A key feature of the 2013 reform was that only the failure flag was erased while the information on entrepreneurs' past failure remained accessible, though at a cost. Thus, an insight of our analysis is that details in the framing of public information strongly matter in shaping the equilibrium. We show that a small friction in accessing information can change drastically how much this information weights in economic agents' decision. When the flag was highly salient, bankers used to heavily penalize individuals that had 
experienced failure in the last three years. Once this information is made less visible, albeit accessible at a small cost, we find that it does not weight as much in conditioning access to credit. This suggests that policy makers ought to be careful when making public information highly visible and need to investigate any potential for stigmatization of certain categories of individuals, and its consequence for market efficiency.

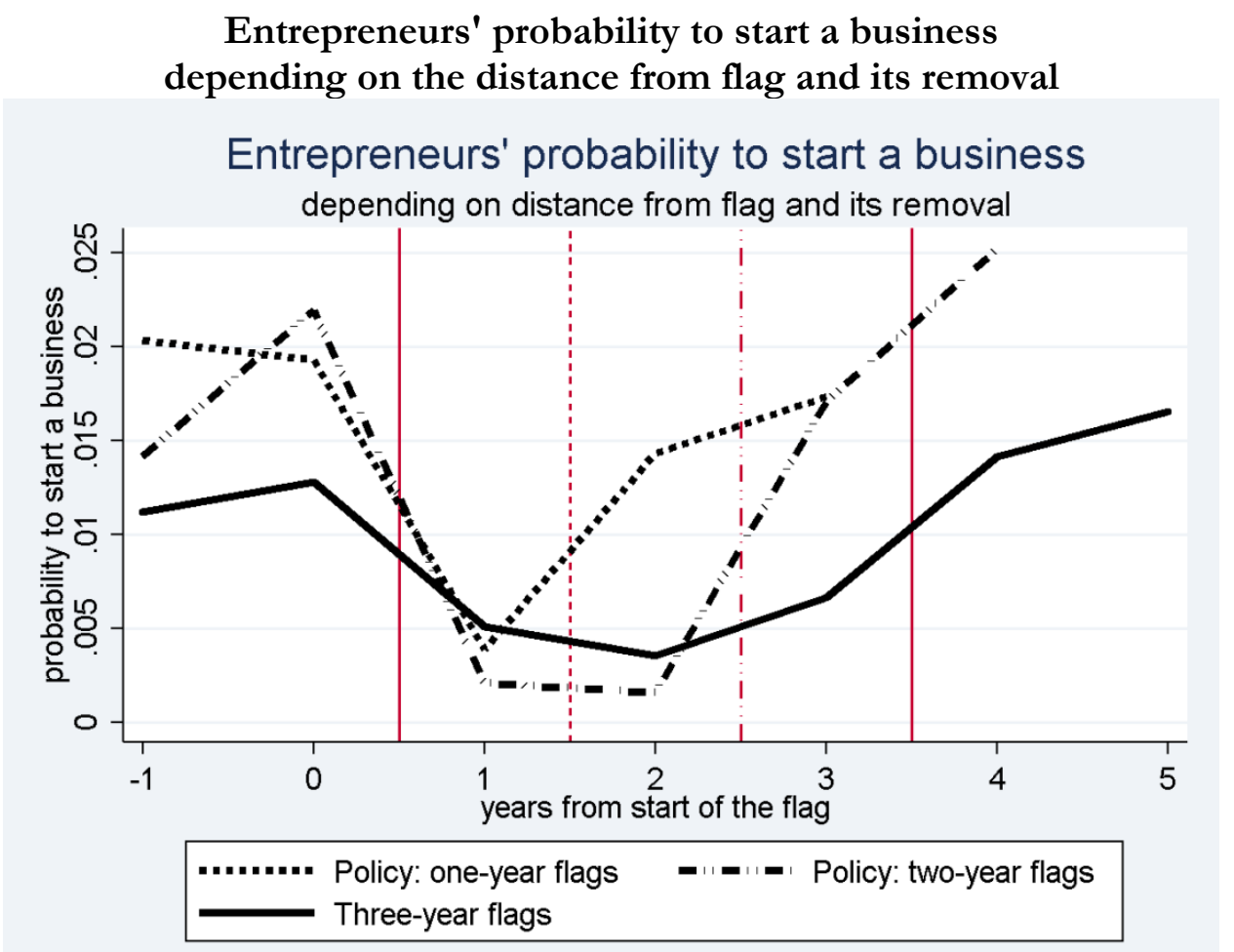

This figure plots the dynamics of entrepreneurs' yearly probability to start a business depending on the distance from the time they are assigned a flag for having failed (first vertical red line) and the event of flag removal. We consider three groups of flags. Those that are affected by the policy change and last one year, those that are affected by the policy change and last two years, and those that last three years (the standard before the policy change). Respectively, the second, third, and fourth vertical lines indicate the corresponding events of flag removal. The plotted dynamics are net of the effects of the manager's age, gender and non-French nationality, and the business cycle.

\section{Entrepreneuriat et information sur les échecs passés : une expérience naturelle}

Nous analysons l'incidence de l'information publique relative aux défaillances passées sur l'accès au crédit des entreprises. Nous exploitons une modification du cadre réglementaire français intervenu en 2013, qui a conduit à la suppression d'un indicateur distinguant les entrepreneurs impliqués dans une liquidation judiciaire non frauduleuse, caractérisé jusqu'alors par une grande visibilité auprès des banques. Nous constatons que l'élimination de cet indicateur a entraîné une hausse significative de la probabilité pour ces entrepreneurs défaillants de recréer une entreprise ainsi qu'un élargissement de l'accès au crédit aux entreprises qu'ils dirigeaient par ailleurs. On observe ces effets alors même que les banquiers peuvent trouver les informations permettant de reconstruire cet indicateur à partir d'autres sources publiques et à faible coût. Les entreprises crées par les entrepreneurs défaillants ont une probabilité de défaut plus élevée.

Mots-clés : entrepreneuriat, accès au crédit, faillite.

Les Documents de travail reflètent les idées personnelles de leurs auteurs et n'expriment pas nécessairement la position de la Banque de France. Ce document est disponible sur publications.banque-france.fr 


\section{Introduction}

A large debate in theoretical and empirical economics is concerned with the optimal public memory of past negative individual outcomes. If information about past failures is never removed from public records, individuals might be permanently deprived from the possibility of a second chance to start a business. This might be inefficient if failure is often due to bad luck and if some failed entrepreneurs have new positive NPV projects for which they need external financing. On the contrary, if failure is mostly due to the poor ability of the manager to rule a business, losing track of her history can lead to a bad allocation of ressources through the financing of negative NPV projects.

In this paper, we analyze the causal impact of public information regarding past corporate defaults on entrepreneurial outcomes. To do so, we exploit a natural experiment that resulted in the elimination of a highly visible record of past corporate bankruptcy for firm managers produced by Banque de France, the French central bank. Before 2013, this individual flagging of managers involved in a bankruptcy was lasting for exactly three years and was made available to banks via Banque de France FIBEN's database, a widely used scoring system of firms and managers. A 2013 reform suppressed the publication of this flag in the FIBEN data for individuals involved in one bankruptcy only. As a result, more than 140,000 individuals were simultaneously deflagged and informed about it. This policy shock allows us to measure how making information on past failures public affects entrepreneurial outcomes.

We find that the flagging of past failures causally impacts (1) the restart probability of failed entrepreneurs, (2) the new corporate loans contracted by flagged entrepreneurs, (3) the interest rate at which they borrow. The significant negative impact of the flag on corporate credit market outcome is somewhat of a surprise as banks can (legally) reconstruct this information based on public bankruptcy files at a very small cost (namely, a few Euros).

We also analyze the impact of information on past failures through the prism of entrepreneurs managing multiple companies: After one of the companies fails, the other companies suffer from the entrepreneur's stigma on the credit market. We show that after the removal of the failure flag, these companies borrow significantly more. This effect is particularly strong in industries where individual talent matters most. We establish this by ranking industries by the dispersion of individual entrepreneurial fixed effects in productivity, using entrepreneurs with multiple 
companies. Industries where individual fixed effects have higher dispersion are those where individual entrepreneurial talent matters most.

Our paper connects to several strands of the literature.

First, in the theoretical literature, several papers model the equilibrium impact of information on past failure: Elul and Gottardi (2015) develop a model in which an optimal length of memory arises; Making information about past default available for longer can deteriorate ex-ante incentives, but improves ex-post incentives, as entrepreneurs whose failure is forgotten want to preserve their reputation. Kovbasyuk and Spagnolo (2016) study a dynamic market game with feedback. In their model, an optimal finite length for negative feedback memory emerges. If negative feedback is kept forever in memory, the market can break down. Landier (2005) analyzes a serial entrepreneurship game in which information on failure can prevent failed entrepreneurs from restarting which can be inefficient if entrepreneurial projects are intrinsically risky.

Second, we contribute to the large empirical literature analyzing the impact of bankruptcy institutions on credit markets. Djankov et al. (2007) document a positive relationship between information sharing through credit bureaus and equilibrium levels of lending.

Rodano et al. (2016) exploit a 2005 reform in Italy facilitating loan renegotiation. They find that the reform increases interest rates and reduces investment, suggesting that more creditorfriendly rules post financial distress can deteriorate entrepreneurial incentives ex-ante.

A large literature studies the impact of limiting negative memory in consumer lending markets. Musto (2004) finds that sudden deletion of negative information creates a boost in creditworthiness but the effect is reversed and even worsened in the long term.

Some papers use a difference-in-difference strategy quite similar to ours to study how information on past personal bankruptcy affects individual outcomes on the credit and labor market: Dobbie et al. (2016) use the removal of personal bankruptcy 'flags' from credit reports in the US as an instrument to document the causal impact of credit score on individual economic outcomes. They use the fact that the maximum legal time bankruptcy information can be kept in credit reports vary by bankruptcy type. Bos and Nakamura (2014) use a policy change in the legal retention time of the flag applied in Sweden to defaulting consumers. They find that shorter retention times result in a restriction of the aggregate supply of credit and a higher like- 
lihood of default. Bos et al. (2016) document that individuals who are flagged longer are more often unemployed and earn lower incomes. They find a large effect of the flag removal on credit card and mortgage borrowing but no impact on labor outcomes. González-Uribe and Osorio (2014) study the impact of a law passed in Columbia, which erased information on past defaults from Private Credit Bureaus files. They find that after information removal, clean borrowers borrow less and tend to swich bank less often, suggesting that the information removal impacts them negatively. While those papers focus on consumer credit, we focus on lending to firms. We are thus among the first to study the effect of failure information on entrepreneurship and firms' access to credit.

Last, our paper relates to the literature on serial entrepreneurs. For instance Lafontaine and Shaw (2014) find that an owner's prior experience at starting a business increases the longevity of the next business opened. This suggests that institutions preventing restart are potentially inefficient as they prevent the use of past experience. Our paper emphasizes the fact that entrepreneurs sometimes run multiple companies at the same time, and exploits the fact that one of the companies might fail while the others survive.

An key insight uncovered by our analysis is that details in the framing of public information strongly matter in equilibrium. We show that a small friction in accessing information can change discontinuously how much this information weights in economic agents' decision. When the flag was highly salient, bankers used to heavily penalize individuals that had experienced liquidation in the last three years. Once this information is made less visible, albeit accessible at a trivial cost, we find that it does not weight as much in conditioning access to credit. This suggests that policy makers ought to be careful when making public information highly visible not to create a form of stigmatization of certain categories of individuals, especially if it is not clear that this stigmatization improves market efficiency. One way to prevent unnecessary stigmatization is to create a small (cognitive or monetary) cost of accessing information. In our example, entrepreneurs who did not fail can still "prove they are clean" at a small cost (they just need to pay the banker to look at the module "Fonctions de Direction" of FIBEN, which costs a few Euros). In turn, this means that the welfare cost associated with removing the flag is capped by the number of would-be entrepreneurs times the cost of "reconstructing" 
a certification equivalent to the flag information based on public data. 1

Section [I] describes the institutional framework underlying Banque de France's information system about individual entrepreneurial failures and presents a summary of the 2013 reform. Section III describes the data and documents the composition of our sample of firms and managers. Section IV presents the empirical results regarding the propensity to restart a company and to borrow as a function of the flag. Last, Section $\mathrm{V}$ explores the policy implications from our analysis. Section $\mathrm{VI}$ concludes.

\section{Institutional Framework}

\section{A Legal Framework for French Firms}

\section{A.1 Legal Form and Managers}

French law defines a firm as the smallest (i.e., non consolidated) legal unit to which it is assigned legal capacity. At the moment of creation, a firm is attributed an identification number (the SIREN number), an indicator identifying the industry, and a legal form (catégorie juridique). Examples of legal forms include joint stock companies $(S A, S A S)$, private limited companies $(S A R L)$, and sole proprietorships $(E I)$. The legal form characterizes the governance type and thus shapes the relationships between shareholders and managers ${ }^{2}$ In fact, the legal form defines the different managing roles (mandat social) for corporate officers: Depending on the legal form, firms may have an Executive or Supervisory Board, a Board Chairman, a managing director (the French equivalent for CEO), a President of simplified joint stock company, and several other subordinated managing roles. Additionally, based on the firm's legal status, only a subset of managing roles are attributed the status of legal representatives (représentant légal) of the firm. Legal representatives are then the only entitled to sign binding contracts for the firm.

\footnotetext{
${ }^{1}$ This insight about the important of salience is reminiscent of Jin and Leslie $(2003)$ who find that restaurant health inspection scores have much stronger impact on consumer demand when they have to be displayed on restaurant windows rather than accessible in a more indirect manner (prior to the reform studied in Jin and Leslie (2003), consumers had to send requests information about violations of an individual restaurant to the administration); hence information was formally available, but rarely used in practice, as in Jin and Leslie (2009).

${ }^{2}$ The terms 'manager' and 'entrepreneur' are used interchangeably thereafter. We do so because (i) the probability that the manager of a newly created company is the entrepreneur is high a priori and (ii) we are interested in companies that are relatively small, for which entrepreneurs are often their managers.
} 


\section{A.2 Bankruptcy Proceedings}

If a firm is unable to service its short-term debt or reimburse its creditors, the firm suspends its payments and its representatives must report a failure (cessation de paiements) to a commercial court 3 A judge then decides either to start an observation period during which a recovery scheme is investigated (a phase called redressement judiciaire), or orders the firm's liquidation (liquidation judiciaire) if recovery seems impossible. During the recovery period, the firm's liabilities are subject to rescheduling but the firm continues to operate, though under the court's scrutinity. If the firm fails to recover after a certain period, it gets liquidated. Otherwise, the situation goes back to normal.

\section{B Information Available to Banks}

\section{B.1 The Banque de France's FIBEN database}

The Banque de France collects information on French non-financial companies and stores it in the FIBEN (FIchier Bancaire des ENtreprises) database. Information include court rulings, trade bill payment incidents, balance sheets, and managers' roles and history. The main reason the Banque de France collects such information is to ease the implementation of monetary policy. In fact, based on the information collected, the Banque de France assigns firms a credit rating 4 Then, in the Eurosystem's refinancing operations, banks can pledge as collateral only claims issued by firms with a sufficiently high credit rating.

French banks have remote access to FIBEN ${ }^{5}$ In this way, they have access to all the information there contained on French non-financial companies. The reason banks access the FIBEN database include, for example, credit risk analysis, assessing the quality of a credit portfolio, and detecting the risks inherent to each lending operation.

\footnotetext{
${ }^{3}$ French law introduced in 2005 the possibility for a firm to access judiciary support, mainly under the form of debt rescheduling, before failure occurs (procédure de sauvegarde). This procedure is similar to the one allowed by the US Chapter 11.

${ }^{4}$ Banque de France's credit ratings are used as an in-house credit assessment system (ICAS) under the General Documentation governing the Eurosystems monetary policy operations.

${ }^{5}$ Access to the FIBEN database, which is granted by French law, has been recently extended to credit insurance companies and assets management funds under agreement with the AMF, the French Market Authority.
} 


\section{B.2 FIBEN's Information on Managers and the Flagging System}

Along with information on firms, FIBEN contains data on the population of executives in France. These include biometric information as well as all current and terminated managing functions each manager has or had in French firms. Furthermore, each manager is assigned a flag called indicateur dirigeant, which records if the manager experienced one or more liquidations as a legal representative.

Until September 2013, the indicateur dirigeant took on four different values: '000', '040', ' 050 ', or '060' depending on whether the manager went into zero, one, two, or at least three liquidations in the preceding three years. Consequently, the flag is time varying, depends on the sequence of liquidations, and is turned on for at most three years after the last liquidation. For example, following the liquidation of a company where a manager was the legal representative, her flag moves from '000' to '040'. After three years without having incurred any other liquidations, her flag goes back to '000'. This course of events is illustrated in the upper panel of Figure 1 .

Figure 1

The manager flag in action

This figure depicts the change in the flag (in boxes) following the occurrence of one or more liquidations.
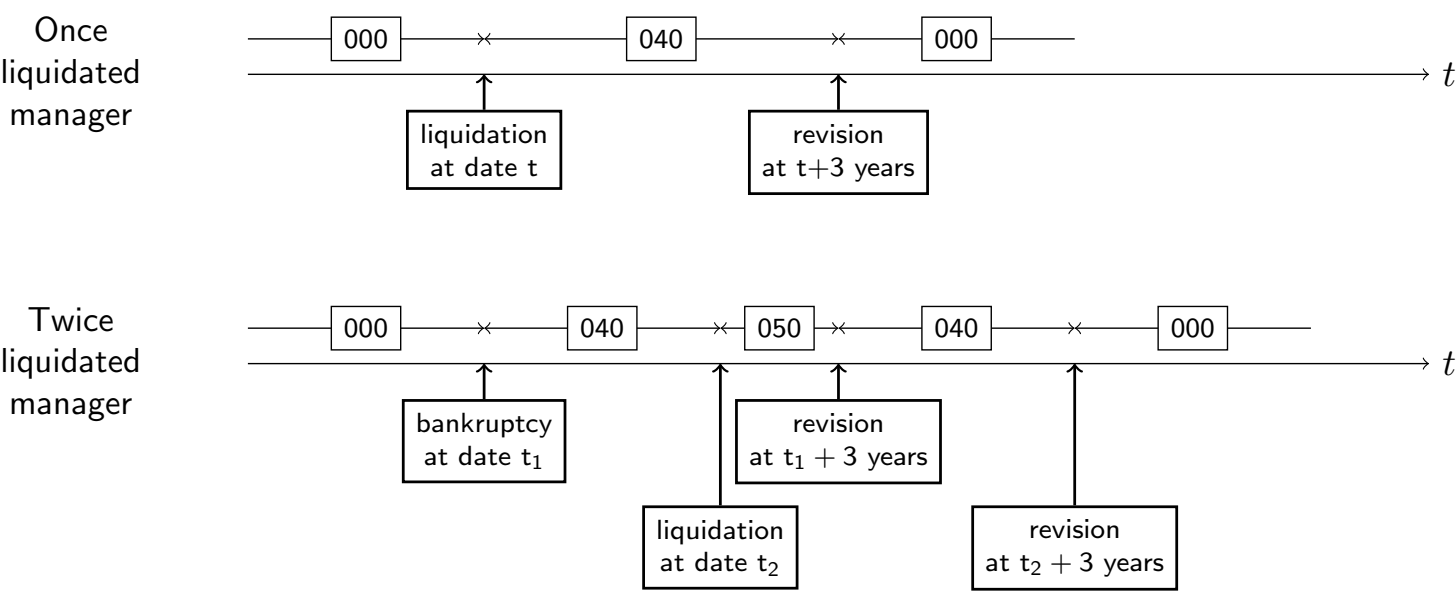

By contrast, the lower panel of Figure 1 shows the change in the flag when the manager experiences two liquidations: the flag is set to '050' as the manager enters her second liquidation. Then, three years after the first event, the flag changes to '040', until three years have passed since the second liquidation, when it returns to ' 000 ' 6

\footnotetext{
${ }^{6}$ All in all, the length of the flag depends on the number of liquidations the manager experienced. If only one liquidation occurred, the most frequently observed case, the duration is exactly three years. However, it
} 


\section{B.3 How Banks Access to FIBEN}

In practice, FIBEN's information is organized by thematic units, or modules (e.g., 'Panorama', 'Managers', 'Credit Rating', and so forth). Bankers access these modules for a fee. For example, in 2015 accessing to the module containing the Banque de France's credit rating cost 3 euros. Browsing the different modules, bankers can collect information on non-financial French firms and their managers. For instance, a banker seeking information on a given manager would access the 'Panorama' module, a snapshot of which is shown in Figure 2, This module returns basic information such as family names and addresses, along with the manager flag.

Figure 2

FIBEN 'Panorama' Module

This figure depicts the FIBEN introductory module 'Panarama' which provides the basic information related to a manager.

\begin{tabular}{llr}
\hline 010152TEST 00 & TEST Jacques & $\begin{array}{r}\text { Indicateur : 060 } \\
\text { depuis le 24/12/2013 (actualisée le 25/09/2014) }\end{array}$ \\
\hline Homonyme & 010152TEST 01 & \\
\hline Adresse & 141 RUE SAINT ANNE & \\
Dossier géré par & BANQUE DE FRANCE : PARIS-BASTILLE & $01 / 01 / 2013$
\end{tabular}

The banker could then access the 'Dirigeant' module, which returns the current managing roles of a manager (see Figure 3) and the functions he or she had over the past three years (see Figure 4). For each firm in which the manager has or had an appointment, the 'Dirigeant' module indicates whether or not the firm has been liquidated (and the date of liquidition, if applicable). By doing this, the banker gathers all the information needed to reconstruct the manager flag.

\section{B.4 Alternative Sources of Information}

FIBEN is not the only source of information on companies and managers. For instance, the French registries of commercial courts provide both free and paid access to a centralized database via the website infogreffe.com. This database also contains financial information and signifmay be the case that for one reason or another (e.g., new resolution from Commercial Court of Appeal, protest against bankruptcy judgment, etc.), the flag duration may be shortened as the triggering event is rendered invalid. Nevertheless these cases are pathological and can be adequately identified in the FIBEN database. 
Figure 3

FIBEN's 'Dirigeant' Module - Current managing functions

\begin{tabular}{|c|c|c|c|}
\hline Gérant & & Depuis le: & $23 / 11 / 2006$ \\
\hline \multicolumn{4}{|l|}{ EXEMPLE PRODUCTION } \\
\hline Identifiant 111111112 & Cotation $\mathrm{F} 4+$ & & Plus d'infos 》 \\
\hline Associé en nom & & Depuis le: & $23 / 11 / 2006$ \\
\hline \multicolumn{4}{|l|}{ EXEMPLE PRODUCTION } \\
\hline Identifiant 111111112 & Cotation $\mathrm{F} 4+$ & & Plus d'infos 》 \\
\hline Associé en nom & & Depuis le : & $22 / 12 / 1995$ \\
\hline \multicolumn{4}{|l|}{ STE DE FINANCEMENT EXEMPLE } \\
\hline Identifiant 111111333 & Cotation $\underline{x_{0}}$ & & Plus d'infos » \\
\hline \multicolumn{4}{|l|}{ Associé en nom } \\
\hline \multicolumn{4}{|l|}{ STE FRANCAISE DES EXEMPLES } \\
\hline Identifiant 111111444 & Cotation | Segmentation $\underline{\underline{X}} \underline{\mid} \underline{\underline{2}}$ & & Plus d'infos » \\
\hline
\end{tabular}

Figure 4

FIBEN's 'Dirigeant' Module - Past managing functions

\begin{tabular}{|c|c|c|c|}
\hline Administrateur & & Depuis le: & $11 / 07 / 2007$ \\
\hline Cessation de fonction & & Depuis le: & $08 / 09 / 2011$ \\
\hline \multicolumn{4}{|l|}{ EXEMPLE AUTOMOBILES } \\
\hline Identifiant 111222000 & Cotation D6 & & Plus d'infos » \\
\hline
\end{tabular}

icant events arising over the lifetime of a company (including events related to bankruptcy proceedings). Moreover, the website search engine allows to search for information on managers and the firms in which she had a managing role. As a consequence, these alternative sources, consisting of proprietary and generally paid-access databases, also make it possible to reconstruct the flag.

\section{The "flag reform" of September 2013}

In September 2013, the French government decided to suppress the '040' level of the flag, and to replace it by ' 000 ' 7 About 140,000 managers benefited from the policy change and hence were "deflagged" at that time, as shown in Table [1. As a consequence, bankers accessing the 'Panorama' module, as shown in Figure 2, cannot directly distinguish between once-liquidated managers and those who have not experienced any liquidations in the past three years.

\footnotetext{
${ }^{7}$ As Fleur Pellerin, the Minister of SME, Innovation and the Digital Economy at that time, puts it: "This is a fact that French society now suffers from not allowing enough a second chance, risking to curb the boldness of his youth and all talents of which France is rich. In the economic field, the totem of this stigma of failure was the "040 indicator", which stigmatized any entrepreneurs having filed for bankruptcy during the previous three years. I fought at the Congress for Entrepreneurship to remove this injustice. In September 2013, 140,000 managers have received a letter from the Banque de France informing them that they would now be treated with the same respect as any new entrepreneur." (03/15/2014, The Huffingtonpost's Blog)
} 
Table I

Breakdown of the managers population according to the manager flags

\begin{tabular}{lrcrrrr}
\hline as of & \multicolumn{2}{c}{ Aug. 2013 } & & \multicolumn{2}{c}{ Dec. 2013 } \\
\cline { 2 - 3 } \cline { 5 - 6 } Flag & Population & Share (\%) & & Population & Share (\%) \\
\hline 000 & 5712990 & 96.9 & & 5917297 & 99.4 \\
040 & 143473 & 2.4 & & 6600 & 0.1 \\
050 & 6276 & 0.1 & & 30878 & 0.5 \\
060 & 31045 & 0.5 & & & \\
\hline Total & 5893784 & 100.0 & & 5954775 & 100.0 \\
\hline
\end{tabular}

However, information about current and past managing roles is still available to bankers via other modules and the alternative sources of information. Hence, the bankers are still able to reconstruct the flag. In fact, the reform also modified the availability of information on past managing roles in the FIBEN system by expanding the time limit of disclosure from three to five years.

\section{Data}

We extract several datasets from the FIBEN database. The first dataset contains information on the date of creation, the industry, and the legal form for the quasi-exhaustive set of French firms existing in 1985 and since then. The date of creation is the date at which a firm is attributed the SIREN number (see Section II) and corresponds to the date at which the firm starts its operations. The industry variable follows the French national activities classification (NAF) and is coded over five digits. Similarly, the legal form follows the classification used in the management of the official French business repository (SIRENE) and consists of a 4-digit index, divided into 9 subdivisions that define the main legal categories (sole proprietorship, business company, public corporation, and so forth).

A second dataset includes information on the whole population of managers. The set of data consists of biometrics variables, namely gender, date, and country of birth, and the information on the flag (i.e. the indicateur dirigeant). For each manager, we know the value of the flag (from '000' to '060'), and the date at which this value is attributed or changed.

The third dataset includes the complete record of manager-firm pairs. Each pair corresponds 
to a specific mandate such as those described in section $\mathrm{II}^{8}$ Since managing roles can tie and untie along time, each manager-firm pair is defined by validity periods, which indicate precisely when the manager is connected to the firm. The combination of the social mandate with the legal form qualifies the manager as legal representative.

The fourth dataset includes information on when each firm incurs a legal event. Specifically, this dataset, which is collected from French commercial courts, records all the different judicial steps leading to a liquidation.

We complement the extracted information with the firm level accounting information available within the FIBEN database. Firms' financial statements are available only for a subsample of the whole population of French firms and are collected when the firm's turnover exceeds EUR 0.75 million. This financial information consists essentially of tax forms that are collected for the computation of Banque de France's credit rating. These tax forms follow the basic French accounting principles and provide us with yearly values for fixed assets such as ground, building, and equipement, trade credit, short and long-term bank debt as well as interest payments, and total assets.

Additionally, we use the French national credit register to compute the number of bank relationships a firm has. This credit register is operated by Banque de France as part of the FIBEN database, and collects bilateral credit exposures between resident financial institutions and non-financial corporations. A bank reports individual credit exposure of all their client firms insofar as total exposure per firm is larger than EUR 25,0009

Before presenting the datasets that we construct from these data, we highlight the importance of entrepreneurs that manage more than one firm at the same time. Managers running more than one firm will enable us to identify the flag's effects on firms that have not been subject to a liquidation. As shown in Table II 'multi-firm' managers account for nearly $16 \%$ of the entire managers' population. The distribution of the number of firms per manager is right-skewed as more than $50 \%$ of these managers are tied to two firms. Importantly, since the sectoral concentrantion is around .25 , it does not appear that multi-firm managers focus on just one industry.

\footnotetext{
${ }^{8}$ Note that managers may have more than one mandate in a firm. For instance, the Chair of the Board may also be the CEO, counting for two different mandates.

${ }^{9}$ Total exposure includes drawn and undrawn credits, as well as guarantee granted by the bank.
} 
In terms of demographics, the average age of multi-firm managers is very similar to that of the rest of the population (Table III). Multi-firm managers tend to be males and French. In terms of the financial conditions of the firms they are related to, Table IV] shows that, compared to other firms, companies run by multi-firm managers are slightly larger in terms of turnover, have a higher leverage ratio, and have slightly less tangible assets.

We now present the three main outputs of the merge of the raw datasets presented above. First, we identify which managers incur a flag, and which firms caused such flags. Those are the firms that went bankrupt at the time the manager was a legal representative. Second, we associate each firm creation to the managers involved in it. Third, we identify if an entrepreneur manages more than one firm at the time she is attributed a flag. If that is the case, we can isolate those surviving firms. We then create two datasets for our econometric analysis: the managers' dataset and the firms' dataset.

\section{A Managers' dataset}

The managers' dataset is a manager-quarter level panel, spanning from 2005Q1 to 2015Q4. It includes all flagged managers and a randomly drawn $5 \%$ of the universe of unflagged managers. Flagged managers are those whose flag duration is three years (the standard before the policy change), and those affected by the policy change and whose flag duration is thus less than three years. Flagged managers are tracked from the first to the eleventh quarter after the start of the flag. A variable 'firm creation' indicates whether the manager creates at least a firm or not (in a given quarter). Other variables detail the managers' demographics.

Table $\mathrm{V}$ presents the summary statistics of the managers' dataset distinguishing by whether managers are flagged or not. A comparison between the two subsamples indicates that flagged managers tend to be slightly younger than unflagged managers on average, but this difference is non statistically significant. Also, the proportion of foreign-born and male managers tend to be higher on average for flagged managers than unflagged ones. For both types of managers, the quarterly rate of firm creation is about $1 \%$.

\section{$B$ Firms' dataset}

The second dataset that we compose is a firm-year level panel, which reports firm-year specific financial information from 2005 to 2014. Firms are distinguished by whether they are 
managed by a flagged manager or not. I isolate firms with maximum one flagged manager along their life. The flags considered include both those lasting three years, and those affected by the policy change and thus lasting less than three years. The firms associated to a flagged manager are created before the start of the flag and are managed by him at the time he gets flagged. Thus, they are not the cause of the flag of the manager. For these firms, only the first, second, and third balance sheets after the flag start are retained, and the flagged entrepreneur manages the company at any of those dates.

Table VI reports summary statistics distinguishing by whether a firm is related to a flagged or unflagged manager. Overall, the two groups do not displays statistically significant differences. Over the sample period, both types of firms experience a deleveraging. Yet, this is slightly more prononced in flagged firms. Also, flagged firms tend to pay a higher, though not statistically significant, loan rate and issue $1 \%$ less of dividends (as of total assets). Finally, flagged firms tend to be smaller than unflagged firms.

\section{Results}

\section{A Restarting after failure}

We start our empirical analysis by looking at how the event of "deflag" impacts the propensity to start a business. In fact, the political motivation for banning the publication of the failure flag was to ease restart for failed entrepreneurs by decreasing the stigma of failure on the credit market.

\section{A.1 Are restarts more likely after the three-year deflag?}

As a first pass at measuring the deflag effect, we focus on the sample of failed entrepreneurs whose flag expired before the reform occured, and thus lasted three years. We call this the "old-regime" sample. We analyze whether such entrepreneurs tend to restart more after the three-year deflag occurs relative to when they are still flagged. In order to remove effects related to, for example, the manager's age or the business cycle, we regress a dummy capturing firm creation over the manager's age, dummies capturing gender and non-French nationality, and time fixed effects. This regression is performed over a sample composed of three-year flagged managers and of managers who have never failed. We isolate the residuals for the group of 
three-year flagged managers, and average them depending on the distance from flag start. Each average represents the probability of starting a business at a given distance from flag start net of the effects of managers' demographic characteristics and the business cycle. Its dynamics is represented by the solid line in Figure 5, where time 0 is when the entrepreneur fails. Three years after he gets deflagged. The assignment of the flag is identified by the vertical solid red line placed after time zero, and the deflag is captured by the vertical solid red line placed after time 3 .

We observe a clear U-shaped pattern, with an upward dynamics at the time the flag is removed. That suggests that when the manager gets flagged its ability to start a business decreases, and when he gets deflagged its ability recovers. To precisely measure the deflag effect on the probability of starting a business, we posit the following Probit model:

$$
\operatorname{Pr}\left(\text { firm }_{\text {creation }} i t=1 \mid X_{i t}\right)=\Phi\left(\delta \mathbb{1}\left\{\text { flag }_{i} \neq \emptyset\right\}+\beta \mathbb{1}\left\{t \geq \text { deflag }_{i}\right\}+\text { controls }_{i}+\eta_{t}\right)
$$

where the dependent variable is the probability of starting a business. As independent variables, flag $_{i}$ represents the quarter at which manager $i$ is attributed the flag, and so $\mathbb{1}\left\{\right.$ flag $\left._{i} \neq \emptyset\right\}$ indicates if manager $i$ has ever received a flag in the past. The dummy $\mathbb{1}\left\{t \geq\right.$ deflag $\left._{i}\right\}$ indicates whether at time $t$ manager $i$ has been deflagged. controls $s_{i}$ include demographic characteristics of manager $i$, and $\eta_{t}$ are time fixed effects. $X_{i t}$ includes all such explanatory variables and $\Phi($. is the cumulative normal distribution function.

Model 1 1 s identification strategy is to compare the restart dynamics before and after the time the manager is deflagged, and attribute the difference to the deflag. We run Model 1 over a sample of managers that never get flagged and of managers that get flagged once in their life with a flag lasting three years (the standard in the old-regime). Note that unflagged managers mainly contribute to the identification of the time fixed effects, and are therefore useful to capture overall rises and slowdowns in the probability to create a business at a given time. However, since the universe of unflagged managers is too large to be managed computationally, and it just serves as a control group, we randomly sample a $5 \%$ subset of it. Moreover, to clean the deflag effect from other trends, flagged managers are analyzed from three quarters before to three quarters after deflag. 
Results appear in the first two columns of Table VII. They indicate that after the manager gets deflagged, he is substantially more likely to create a business. Relative to unflagged managers, flagged managers are also on average more likely to create a business, reflecting the need to restart after a failure. Finally, younger as well as male and non-French individuals are associated to a greater probability to create a business.

It is however difficult to conclude from this analysis alone that the flag has a causal impact on restart: after all, it might be that after a failure, entrepreneurs take a few years to find a new project or simply to recover psychologically. What we attribute to the deflag effect may then be an upward trend, due to such "natural" recovery.

\section{A.2 Measuring the flag effect via the policy shock}

The policy shock offers us an identification strategy that overcomes the limits of just looking at the before-after dynamics of old-regime flags. When the reform is enacted, more than 140,000 entrepreneurs previously flagged by the Banque de France get deflagged and among them, some have failed one year or two years before. We can compare their dynamics after the start of the flag to that of the cohort of entrepreneurs that failed in the old-regime and were thus flagged for three years. Controlling for the time distance from flag start (and other observable characteristics), the only difference with the entrepreneurs deflagged by the reform is the flag itself. Hence, the reform allows a causal interpretation of the effect of the deflag on the propensity to restart.

We first repeat the graphic analysis of Subsection A.1. We complement the sample of neverfailed managers and three-year flagged managers with policy-affected managers whose flags last either one or two years. We then regress the dummy capturing firm creation over the manager's age, dummies capturing gender and non-French nationality, and time fixed effects. We isolate the residuals within each group of flagged managers, and average them depending on the distance to flag start. As before, each average represents the probability of starting a business at a given distance from flag start net of the effects of managers' demographic characteristics and the business cycle. The dynamics are represented in Figure 5. Comparing the pattern of restart of the policy-affected groups to the one of the pre-reform regime group (solid line) as a function of the time since flag start, it appears very clearly that the early deflag induced by the reform 
causes an early rise in restarts.

The econometric strategy reflects this graphical analysis and compares the dynamics of three-year flagged managers and policy-affected managers depending on the distance from the flagging event. We are then led to a difference-in-differences Probit model of the form:

$\operatorname{Pr}\left(\right.$ firm $\left._{\text {creation }}{ }_{i t}=1 \mid X_{i t}\right)=\Phi\left(\sum_{q=1}^{11} \gamma_{q} \mathbb{1}\left\{t=\right.\right.$ flag $\left._{i}+q\right\}+\beta \mathbb{1}\left\{t \geq\right.$ deflag $\left._{i}\right\}+$ controls $\left._{i}+\eta_{t}\right)$

where $\operatorname{flag}_{i}$ is the quarter at which manager $i$ is attributed the flag, and $\mathbb{1}\left\{t=\right.$ flag $\left._{i}+q\right\}$ are thus eleven time-from-flag-start dummies, ranging from the first to the eleventh quarter after flag start. deflag is the quarter at which the manager gets deflagged, and therefore $\mathbb{1}\left\{t \geq\right.$ deflag $\left._{i}\right\}$ indicates whether at time $t$ manager $i$ has been deflagged. controls $s_{i}$ include demographic characteristics of manager $i$, and $\eta_{t}$ are time fixed effects. $X_{i t}$ includes all such explanatory variables and $\Phi($.$) is the cumulative normal distribution function.$

The model is run over a sample composed of 1) managers that never get flagged, 2) managers that get flagged once in their life, with a flag lasting three years (the standard in the old regime), and 3) managers that get flagged once in their life, were affected by the policy change, and thus experienced a flag lasting less than three years. For the two groups of flagged managers we focus on the period between the first and the eleventh quarters after flag start. Note that the group of unflagged managers contribute to the identification of the time fixed effects. They are thus useful to capture overall rises and slowdowns in the probability to create a business at a given time. This is particularly needed in our estimation as three-year flagged managers and policy-affected managers get flagged at different points in time. So, in order to compare their dynamics we need to absorbe time fixed effects. However, since the universe of unflagged managers is too large to be managed computationally, we need to randomly sample a $5 \%$ subset of it.

The key parameter of interest is $\beta$, which measures the impact of being deflagged on the quarterly propensity to start a business. The time-from-flag-start dummies capture the benchmark dynamics that policy-affected managers would have taken if the reform was not passed. So, $\beta$ captures the deviation from such dynamics that happens after the flag is removed. Note that the identification of $\beta$ happens purely through the early deflags. In fact, between the first 
and the eleventh quarters after flag start, the managers whose flag lasts three years are still flagged.

Results appear in the third and fourth columns of Table VII. They confirm that the deflag is associated to a higher probability of creating a business. According to column 3 , the conditional probability of starting a business in a quarter is $.67 \%$ at the median. The deflag is associated to an increase of .15\%. Similarly to what found earlier, younger as well as male and non-French individuals are associated to a greater probability to start a business. Overall, these results suggest that the flag reduces the ability to restart for an entrepreneur.

\section{A.3 New firms' productivity}

We analyze the productivity of firms created by flagged managers vis-à-vis firms created by unflagged managers. Our sample includes firms created after 2005 by either unflagged managers, old-regime flagged managers, and policy-affected flagged managers. We retain the first balance sheet appearing in the FIBEN system if presented within three years from the date of creation. We then study the Return on Assets (ROA, defined as EBITDA over total assets), and the EBITDA over total sales as a function of whether at the creation the manager is flagged, or deflagged. Other controls include log total assets, year and industry fixed effects.

Table VIII shows that according to both productivity measures, firms created by a manager who received a flag are less productive at restart. This is particularly the case if the firm is created while the manager is still flagged.

We complement these results by studying firms' financial conditions at creation. We use the same econometric approach and consider leverage (bank debt over total assets), loan rate effectively paid, and trade credit (total payables less total receivables, over total assets) as dependent variables. Results appear in Table XIX. Relative to firms created by unflagged managers, firms created by a manager who has received a flag in the past lack of bank debt. This is especially true if the firm creation happens while the manager is still flagged. This result suggests that entrepreneurs have a lower ability to borrow while being flagged. In the same vein, the loan rate is higher if the manager has received a flag in the past, and more so if the creation happens while he is still flagged. Lacking bank debt, firms substitute it with trade credit. Indeed, we observe that firms created while the manager is still flagged display 
more trade credit than firms created while the manager has been deflagged. The results on the financial conditions may pair with those on productivity. When new firms do not have access to sufficient funding, they may underinvest. This may explain why firms created by a manager who is flagged are less productive at restart.

We check if the observed differences at restart persist in the medium run and study both the productivity and the financial conditions of newly created firms after six years from creation. Tables IX and $\mathrm{XX}$ report the results. After six years from creation, firms do not display significant differences in their productivity depending on whether their manager has ever been flagged or was flagged at the time the firm was created. Likewise, firms started at the time the manager is flagged do not display significant differences in terms of bank debt over total assets and loan rate relative to firms created by unflagged managers. However, they do display higher levels of trade credit. Conversely, after six years from creation, firms started by a failed manager but deflagged at the time of creation are more levered and pay higher loan rates than firms started by unflagged managers.

The main drawback of the results presented is that the sample does not include every newly created firm. To be in our firms' balance sheet database, in fact, firms need to be sufficiently large. Since newly created firms are on average small, our sample accounts for a minority of them, and the sample size is not sufficient to perform the difference-in-difference identification strategy used in subsection A.2. Ideally, we would like to study productivity and financial conditions of firms created by flagged managers differentiating by whether creation happens while the manager has already been deflagged, holding constant the distance from the flag start. As before, we would focus on the 36 months right after flag start, and the deflag effect would be estimated thanks to the early deflag induced by the policy change. However, that requires to have a sufficient number of firms created within 36 months from flag start in both old regime and policy-affected managers, and this is not the case in our sample.

\section{A.4 New firms' probability of failure}

The results obtained so far indicate that banks limit the funding to failed entrepreneurs as soon as they observe the failure flag. This may be because the flag makes a past failure immediately visible and banks associate a past failure to greater risk. Our dataset can clarify 
if failed entrepreneurs are actually more likely to fail again.

The sample of firms we consider is composed of a randomly drawn $15 \%$ of the universe of firms created after 2005. We then study if firm failure depends on whether one of the firm's manager has been involved in a failure and on whether he is currently flagged. The Probit model writes:

$$
\begin{aligned}
\operatorname{Pr}\left(\text { firm fails }_{j q}=1 \mid X_{i t}\right) & =\Phi\left(\sum_{y=1}^{5} \gamma_{y} \mathbb{1}\left\{\text { year }(q)=\operatorname{year}\left(\text { fail }_{j}\right)+y\right\}\right. \\
& \left.+\beta \mathbb{1}\left\{\text { flag }_{j} \leq q \wedge q \leq \text { deflag }_{j}\right\}+\zeta \text { age }_{j q}+\eta_{\text {industr }_{j} ; q}+\eta_{j}\right)
\end{aligned}
$$

where the dependent variable is the probability of firm failure. year $(q)$ is the year of quarter $q, f_{a i l}$ is the quarter in which $j$ 's manager failed, flag $g_{j}$ is the quarter in which the manager was assigned the flag, and deflag $g_{j}$ is the quarter in which the flag was removed. Therefore, $\mathbb{1}\left\{\right.$ year $(q)=$ year $\left(\right.$ fail $\left.\left._{j}\right)+y\right\}$ are time-from-manager-failure dummies, and $\mathbb{1}\left\{\right.$ flag $\left._{j} \leq q \wedge q<\operatorname{deflag}_{j}\right\}$ indicates if the firm's manager is flagged at $q$. Additionally, age $j q$ is the firm's age at $q$, and $\eta_{\text {industry }_{j} ; q}$ are industry x quarter fixed effects. $X_{i t}$ includes all such explanatory variables and $\Phi($.$) is the cumulative normal distribution function.$

The sample includes firms with managers that never fail, and managers that fail. In the latter case, we focus on observations up to the fifth year after the manager's initial failure. Failed entrepreneurs include either those that fail before or after the policy change. It is important to note that we consider all types of flag and we do not restrict our attention to failed managers with a three-year flag or a policy-affected flag. Otherwise, by construction, we would focus only on those flagged managers who do not fail again, thus biasing the estimation.

The five parameters $\gamma_{y}$ capture to what extent a failed manager is more or less likely to fail after an initial failure. The identification of these parameters works by comparing the probability of failure of a firm with a manager who failed for example one year before with the probability of failure of a firm with a manager that never failed. Clearly, until the first failure, a manager has never failed in his life. So, the identification of $\gamma_{y}$ is achieved measuring the difference in the probability of failing a second (or third, fourth, etc.) time vis-a-vis the probability of failing the first time. 
$\beta$ measures the effect of the manager being currently flagged on the probability of failure. Disentangling the effect of being flagged from the effect of the past failure is possible because the managers in the sample are not flagged over the entire five-year period that follows the initial failure. In fact, the flags considered have very heterogeneous duration. First, the old-regime flags last three years. Second, as described in Section II] if the manager fails again within three years from the initial failure the flag lasts more. Third, the policy-affected flags have a duration shorter than three years. Fourth, all managers that fail after the policy change are not flagged. As a consequence, for any time distance from failure, the sample includes failed managers that are flagged and managers that are not flagged. This enables us to identify the effect of being flagged separately from the effect of having failed.

Table $\mathrm{X}$ presents the results, with each of the four columns analyzing a different event of failure. The dependent variable in Column 1 captures whether the firm fails the following quarter. In column 2, this is replaced by an indicator of whether failure happens over the following year but that is the last quarter the entrepreneur manages the firm. In column 3 , the dependent variable is an indicator of whether the firm is involved in a legal proceeding. Finally, in column 4 , the dependent variable is a combination of whether the firm fails over the following quarter and of whether the firm is currently involved in a legal proceeding.

All columns point in the same direction. A manager that has been involved in a past failure is more likely to fail again. The probability of failing again does not change with the distance from the initial failure. Taking the last column, a median firm has quarterly probability of failure equal to $.65 \%$. If that firm is managed by a manager that has failed less than one year before, that probability increases by $.79 \%$. Thus, the probability of failure more than doubles. At the same time, the manager being flagged is associated to a further increase in the probability of failing again. The increase due to this effect for the median firm would be of $.36 \%$. We interpret this second effect as coming from the fact that the flag leads to a decrease in lending to the firm, and thus to suboptimal investment. The ultimate effect is then a higher probability of failure. 


\section{$B$ The effect of the failure flag on the existing firms managed by the entrepreneur}

The previous subsection has focused on the ability of flagged entrepreneurs to restart. The estimated effects may be considered as those related to the extensive margin of the failure flag. We focus here on firms which are managed by a flagged manager at the time he receives the flag, but are not causing the attribution of the flag themselves and continue to operate. We follow the strategy used in subsection $A$ and study the dynamics of those surviving firms as a function of the deflag. Our goal is to estimate if after the flagging of the manager those companies borrow relatively less and start to borrow more after the flag is removed. This may be interpreted as the intensive margin of the failure flag.

\section{B.1 Do bank debt and investment increase after the three-year deflag?}

We repeat the strategy followed in subsection $A .1$ and start our analysis by tracking the debt dynamics of the firms associated to old-regime flagged managers in the periods around the flag and the deflag. We define the yearly change in bank debt deflated by lagged total assets as a measure of loan supply to the firm. We consider a sample of firms that are never associated to a flagged manager, and firms associated to just one flagged manager. For the latter firms, we retain old-regime flags, which thus last three years. We then regress the normalized change in bank debt over firm and industry $\mathrm{x}$ time fixed effects. In this way we absorbe industry dynamics and time-invariant effects related to the firm. We obtain the residuals for the group of firms with flagged managers, and take the average at any distances from flag start.

The resulting dynamics is described by the solid line in Figure6. The pattern is U-shaped, with a decreasing trend before the flag is assigned, and an upward trend when the flag is removed. This is remarkably similar to what found for the probability to start a business.

The decrease in the change in bank debt starts before the flag is assigned. The reasons for such early decrease may be at least two. First, since the manager is experiencing a hard time with one firm, which eventually fails, he may reduce the demand for credit in the other firms he manages. This may be the case especially if those firms have complementarities with the failing one. Second, before the firm gets liquidated, bankers may observe that it is experiencing a hard time, and may perceive the entrepreneur as riskier. Thus, they may reduce the credit to the other firms he manages. As a result at the moment the flag is assigned, supply effects mix 
with demand effects. At deflag, the case is different. Unless managers increase their willingness to borrow exactly three years after the flag is assigned, their demand for credit does not differ before and after deflag. Thus, the upward trend around that point may be attributed to an increase in banks' willingness to lend.

We provide the econometric counterpart of Figure 6, exploring also the change in shortterm and long-term bank debt, the loan rate, the change in trade credit, different investment components, and the dividends distributed. The econometric model writes:

$$
\frac{x_{j t}}{\text { total assets }_{j t-1}}=\beta \mathbb{1}\left\{t \geq \operatorname{deflag}_{j}\right\}+\eta_{\text {industry }_{j} ; t}+\eta_{j}
$$

where $j$ is a firm, $t$ is a year, and the dependent variable $\frac{x_{j t}}{\text { total assets }_{j t-1}}$ is a variable of interest $x$, for example change in bank debt or investment in equipments, normalized by lagged total assets. $\mathbb{1}\left\{t \geq \operatorname{deflag}_{j}\right\}$ indicates whether firm $j$ 's manager has already been deflagged at year t. $\eta_{\text {industry }} ;$ t and $\eta_{j}$ are respectively industry x time fixed effects and firm fixed effects.

Equation (4) is estimated over a sample composed of firms that are never associated to a flagged manager, and firms associated to just one old-regime flagged manager. For the latter firms, we retain observations from two years before to two years after the deflag realizes. $\beta$ is the main parameter of interest, and its identification is achieved comparing the trajectories before and after deflag.

Results appear in Tables XI and XII. They suggest that bank debt and investment increase after deflag, and correspondingly the loan rate decreases. This is indication that banks reduce their lending to existing firms whose managers get flagged. However, the identification rests on the assumption that managers do not modify their demand for credit exactly three years after the flag is assigned. Since this assumption may not be valid, we proceed exploiting the policy shock of September 2013 in a difference-in-difference setting similar to the one explained in subsection $A .2$,

\section{B.2 Measuring the flag effect via the policy shock}

The policy change of September 2013 exogenously erased all existing flags irrespectively of when they were assigned. As a result, the affected flags lasted less than three years, and had heterogeneous durations. We identify the deflag effect comparing the trajectory of firms with 
old-regime flagged managers and firms with policy-affected managers. Holding constant the distance from flag start, the only difference in the two trajectories is due to the reduced flag duration of the policy-affected managers.

We first provide a graphical comparison of the trajectories of firms with old-regime and policy-affected managers. As in subsection B.1, we saturate the change in bank debt deflated by lagged total assets with industry x time and firm fixed effects, and obtain the residuals. We group firms depending on whether the manager's flag is old-regime, or is policy-affected and lasts 1 year, or is policy-affected and lasts 2 years. We then take the average of the residuals within group and time distance from the start of the flag. Figure 6 plots the three curves. All share a decreasing trend around the time the flag is assigned, but show a clear upward trend at the time each group gets deflagged.

We then proceed with the econometric counterpart of the figure presented. We consider a sample composed of firms whose managers fall in one of the following categories: unflagged managers, old-regime flagged managers, and policy-affected managers. At most one of the managers may be flagged along the life of a firm. This is to ensure that we can precisely identify what flag applies to the firm and when it starts and ends. Firms with a flagged manager are tracked from the first year after flag start up to the third year. The model then writes:

$$
\begin{aligned}
\frac{x_{j t}}{\text { total assets }_{j t-1}}=\gamma_{1} \mathbb{1}\left\{t=\text { flag }_{j}+2 y r s\right\}+\gamma_{2} \mathbb{1}\{ & \left.=\text { flag }_{j}+3 y r s\right\} \\
& +\beta \mathbb{1}\left\{t \geq \text { deflag }_{j}\right\}+\eta_{\text {industry }_{j} ; t}+\eta_{j}
\end{aligned}
$$

where $j$ is a firm, $t$ is a year, and the dependent variable $\frac{x_{j t}}{\text { total assets }_{j t-1}}$ is a variable of interest $x$, for example change in bank debt or investment in equipments, normalized by lagged total assets. $\mathbb{1}\left\{t \geq \operatorname{deflag}_{j}\right\}$ indicates whether firm $j$ 's manager has already been deflagged at year $t$. The main innovation of equation (5) relative to equation (4) is the addition of $\mathbb{1}\left\{t=f\right.$ lag $\left._{j}+2 y r s\right\}$ and $\mathbb{1}\left\{t=f l a g_{j}+3 y r s\right\}$. These dummy variables indicate whether year $t$ is the second, respectively third, year after the start of the flag that happens at $f l a g_{j}$. They thus control for the dynamics taken by a firm after its manager is assigned the flag. As in equation (4), $\eta_{\text {industr }} ;$; and $\eta_{j}$ are respectively industry $\mathrm{x}$ time fixed effects and firm fixed effects.

Identification comes as follows. Industry dynamics (i.e. $\eta_{\text {industry }} ; t$ ) is mainly identified from 
the sample of firms with no flags. Controlling for it, we remove every industry-specific pattern that affects firms' desires to demand credit (or invest) and banks' willingness to lend. The effects of the two dummies that control for the distance from the assignment of the flag are identified from the firms with flagged managers. They isolate, for example, the pattern in firms' demand that is due to the managers having been flagged. The main comparison is then between firms whose managers are affected by the policy-induced early deflag and firms whose managers are not.

As a result, $\beta$ captures the difference in the dynamics of policy-affected firms and policyunaffected firms due to the deflag, holding constant the distance from the attribution of the flag and the industry dynamics. Its identification is possible thanks to the fact that policy-induced deflags happen at different time distances from the attribution of the flags, and earlier than three years from the flag assignment. Note, in fact, that since the observations of the firms with flagged managers are included up to three years after the flag assignment, the sample does not include the events of deflag of the old-regime flagged managers. The deflag effect is thus estimated from the group of policy-affected flagged managers only.

Results appear in Tables XIII and XIV] Consistently with the results obtained exploiting the three-year discontinuity, bank debt and investment in plant increase after deflag, and the loan rate decreases. This corroborates the idea that even with existing firms, the attribution of the flag to the firm's manager decreases the loan supply to the firm, and the ability to invest.

\section{B.3 Cross-sectional differences}

We enrich our analysis by studying cross-sectional differences of the deflag effect. In theory, banks should put more weight on past entrepreneurial failure (1) in sectors where the volatility of the cash-flows and the probability of failure are high, and (2) in sectors where individual talent matters more. Indeed, in a sector where the volatility of the cash-flows or the probability of failure are low, the increase in risk due to the fact that the entrepreneur has already failed may be a lower concern. Similarly, when individual talent matters less for performance, there is less reason to expect that another venture of a failed entrepreneur might be of poor quality.

We compute an industry-specific measure of the volatility of cash flows. We take the universe of firms, and regress the Returns on Assets over time fixed effects. We take the standard 
deviation of the residuals within each firm, and then average it within 3-digit industry group. We obtain the distribution of that statistic and split the sample in terciles. Finally, we modify model (5) interacting $\mathbb{1}\left\{t=\right.$ flag $\left._{j}+2 y r s\right\}, \mathbb{1}\left\{t=\right.$ flag $\left._{j}+3 y r s\right\}$, and $\mathbb{1}\left\{t \geq\right.$ deflag $\left._{j}\right\}$ by a dummy capturing whether the firm's industry is in the top tercile, and therefore displays a high volatility of cash-flows. Results appear in Table XV. They confirm the theoretical predictions: banks assign more weight to the failure flag in industries where the volatility of cash-flows is high.

Similarly, we compute an industry-specific measure of firm failure. We take the universe of firms, and regress a dummy capturing firm failure over time and industry fixed effects. When estimated the 3-digit industry fixed effects, we compute their distribution, and split the industries in terciles. Finally, we modify model (5) interacting $\mathbb{1}\left\{t=\right.$ flag $\left._{j}+2 y r s\right\}, \mathbb{1}\{t=$ $\left.\operatorname{flag}_{j}+3 y r s\right\}$, and $\mathbb{1}\left\{t \geq \operatorname{deflag}_{j}\right\}$ by a dummy capturing whether the firm's industry is in the top tercile, and therefore shows a high probability of firm failure. Results appear in Table XVI. They confirm the results of Table XV] and show that banks reduce lending to flagged managers especially in those industries in which failure is more likely.

Next, we use a methodology from Bertrand and Schoar (2003) to identify the importance of talent in a given industry. We take the universe of firms and construct a panel where the unit of observation is (entrepreneur, firm, time). The fact that some managers $i$ run multiple firms $j_{1}, j_{2}$ and some firms $j$ are run by successive managers allows us to estimate manager fixed effects in the regression:

$$
R O A_{i, j, t}=\eta_{i}+\eta_{j}+\eta_{\text {industry }_{j} ; t}
$$

where the manager fixed-effect, $\eta_{i}$, measures common productivity of firms run by the same individual. For each 3-digit industry, we measure the dispersion of individual fixed effects, which we use as a proxy for how much individual talent matters for productivity in that industry. Industries are split in terciles depending on the average dispersion. We then modify model (5) interacting $\mathbb{1}\left\{t=\right.$ flag $_{j}+2$ yrs $\}, \mathbb{1}\left\{t=\right.$ flag $\left._{j}+3 y r s\right\}$, and $\mathbb{1}\left\{t \geq\right.$ deflag $\left._{j}\right\}$ by a dummy capturing whether the firm's industry is in the top tercile, and therefore individual talent matters a lot for productivity in the industry. Results appear in Table XVII. They suggest that banks reduce their funding more when individual abilities matters more, as a past failure in that case is more 
indicative of worse managerial abilities.

\section{B.4 Do firms borrow from new banks after deflag?}

When an entrepreneur fails with one firm, the banks that deal with him observe the failure directly. Then, when he applies for funding with a surviving company, such banks may still remember his past failure without searching on FIBEN. If that is the case, we should observe that the increase in bank debt at deflag primarily comes from new banks. Moreover, according to this argument, there should be an increase in the number of bank relationships after the manager gets deflagged.

We test this idea exploiting model (6) and using as dependent variable the change in the number of bank relationships. This variable is obtained first counting the number of banks a given firm deals with as appearing in the credit register data, and then taking the year change. Table XVIII presents the results. They confirm that firms increase the number of bank relationships after deflag. This corroborates the idea that, for banks, the flag is a primary element to assign credit when they do not have prior relationship with the firm.

\section{Policy implications}

Welfare and redistributive implications of a policy that changes the information sets of agents are in general hard to evaluate. It might for example be the case that restricting information on failure makes the rates at which other entrepreneurs borrow higher, or hurts their incentives; After all if the stigma of failure is lower, entrepreneurs might be less cautious. Also, we do not observe the outside options of failed entrepreneurs, which makes it hard to assess the loss from a delayed restart.

However, in the case of the 2013 reform which we analyze in this paper, we can be somewhat assertive about the induced cost of the reform: Indeed, the information about past failures can be reconstructed by market participants at the cost of a few euros. This means that an entrepreneur who wants to separate from the pool of entrepreneurs by proving that she has a clean slate can do so at a small cost and return to the equilibrium prevailing before the policy change. Our regressions show that this pre-reform equilibrium is separating, in that flagged entrepreneurs are treated differently from non-flagged ones. In turn, this suggests that the individual welfare 
cost borne by non-failed entrepreneurs due to the reform is smaller or equal to this small cost of signaling they are clean. Regarding "failed entrepreneurs", assuming that they are rational agents, it is clear that the reform has a positive impact on them as the number of early restarts rises. For this fraction of the population, the gains from the reform are likely to be of a higher order of magnitude than a few Euros; but a precise estimate would require a measure of the outside options of this population. Of course, if one believes that serial entrepreneurs are over-optimistic (see e.g., Landier and Thesmar $(\overline{2009})$ ), one might argue that the restarts by failed entrepreneurs might be inefficient. However, firms restarted by entrepreneurs with prior liquidations do not appear strongly less productive than their peers. They are more risky in a significant manner, but this remains a relatively small effect. The aggregate cost of the reform is theoretically ambiguous: Failed entrepreneurs who benefit substantially are a small group, whereas non-failed entrepreneurs are a larger group. Policy makers might also anticipate that by reducing the stigma of failure, the reform might increase the number of first-time entrepreneurs, which might be welfare enhancing. Basically, what one can confidently conclude is the following: The reform substantially improves access to credit for failed entrepreneurs and the individual cross-subsidy induced by the reform is not costing more than a few Euros to "clean" entrepreneurs as they can still establish their status at such small cost.

Our analysis also shows that banks do not all "reconstruct the flag". Otherwise, we should not observe the significant changes in early restarts that we document. This can seem surprising given the small cost of reconstruction and begs the question of whether this is an optimal response on the part of the banks. This is a complex question as organizational costs and incentive constraints within banks are not observable. However, a crude back-of-the-envelope computation can shed some light on this question. Let us start from a pooling equilibrium where banks do not bother reconstructing the flag and ask whether the cost of reconstructing is less than the potential expected loss coming from lending to a failed entrepreneurs.

First, we can compute the base rate of entrepreneurs who failed in the last three years in the population of entrepreneurs: It is the rate of flagged managers pre-reform, i.e. $2.5 \%$. The median debt level in our sample is EUR 54k. The additional yearly mortality given past failure is around $2 \%$. Assume 5-year debt with zero recovery (which is a worse case scenario): The expected additional loss from lending to a failed entrepreneur is $2.5 \% * 54 \mathrm{k} *(5 * 2 \%)=\mathrm{EUR} 135$. This is 
an upper bound as it assumes zero recovery rate and a non-incremental loan. It suggests that bankers might be acting optimally (or close to optimally) in not systematically reconstructing the flag such as to implement the pre-reform equilibrium.

To conclude, the reform can be seen as substantially alleviating the poorer access to credit of a fraction of the population at a cost that is bounded to be a few Euros for other entrepreneurs. In turn, the lower fear of post-failure outcomes might in theory have increased the expected value of becoming an entrepreneur. There might be a general lesson for policy-making here: Details in the framing of public information seem to matter strongly in equilibrium. This suggests that policy makers ought to be careful when they make public information highly visible not to create a form of stigmatization of certain categories of individuals especially if it is not clear that this stigmatization improves market efficiency. One way to prevent unnecessary stigmatization is to create a small (cognitive or monetary) cost of accessing information.

\section{Conclusion}

This paper studies the causal effect of information on past entrepreneurial liquidations on the ability to access corporate credit markets and restart a business. We take advantage of the suppression by a 2013 legal reform of a salient flag on past liquidations provided by Banque de France to banks. We find that deflagged entrepreneurs tend to restart a business sooner and benefit from better credit conditions than prior to the reform. This happens despite the fact that the flag can be "reconstructed" by bankers based on other public data sources at a small cost. Changing the salient Banque de France flag on prior liquidations into an information that can be accessed at a small cost strongly improves the equilibrium outcome for individuals that used to suffer from the stigma of past failures. This result has possibly important policy implications. It suggests that policy makers can avoid public information to stigmatize certain categories of individuals by avoiding negative information to be too salient. 


\section{References}

Bertrand, Marianne and Antoinette Schoar, "Managing with style: The effect of managers on firm policies," The Quarterly Journal of Economics, 2003, 118 (4), 1169-1208.

Bos, Marieke and Leonard I Nakamura, "Should defaults be forgotten? Evidence from variation in removal of negative consumer credit information," 2014.

_ , Emily Breza, and Andres Liberman, "The labor market effects of credit market information," 2016.

Djankov, Simeon, Caralee McLiesh, and Andrei Shleifer, "Private credit in 129 countries," Journal of Financial Economics, 2007, 84 (2), 299-329.

Dobbie, Will, Paul Goldsmith-Pinkham, Neale Mahoney, and Jae Song, "Bad credit, no problem? Credit and labor market consequences of bad credit reports," 2016.

Elul, Ronel and Piero Gottardi, "Bankruptcy: Is It Enough to Forgive or Must We Also Forget?," American Economic Journal: Microeconomics, 2015, 7 (4), 294-338.

González-Uribe, Juanita and Daniel Osorio, "Information sharing and credit outcomes: Evidence from a natural experiment," 2014.

Jin, Ginger Zhe and Phillip Leslie, "The effect of information on product quality: Evidence from restaurant hygiene grade cards," The Quarterly Journal of Economics, 2003, 118 (2), 409-451.

_ and _, "Reputational incentives for restaurant hygiene," American Economic Journal: Microeconomics, 2009, 1 (1), 237-267.

Kovbasyuk, Sergei and Giancarlo Spagnolo, "Memory and Markets," 2016.

Lafontaine, Francine and Kathryn Shaw, "Serial Entrepreneurship: Learning by Doing?," 2014.

Landier, Augustin, "Entrepreneurship and the Stigma of Failure," 2005.

- and David Thesmar, "Financial contracting with optimistic entrepreneurs," Review of financial studies, 2009, 22 (1), 117-150.

Musto, David K, "What happens when information leaves a market? evidence from postbankruptcy consumers," The Journal of Business, 2004, 77 (4), 725-748.

Rodano, Giacomo, Nicolas Serrano-Velarde, and Emanuele Tarantino, "Bankruptcy law and bank financing," Journal of Financial Economics, 2016, 120 (2), 363-382. 


\section{Figures}

Figure 5

Entrepreneurs' probability to start a business depending on the distance from flag and deflag This figure plots the average residuals in the entrepreneurs' yearly probability to start a business depending on the distance from the flagging and deflagging events. We consider three groups of flags. Those that last three years (the standard in the old regime), those that are affected by the policy change and last one year, and those that are affected by the policy change and last two years. Preliminary, we regress a dummy capturing firm creation over the manager's age, dummies capturing gender and non-French nationality, and time fixed effects. The regression is performed over a sample composed of managers with one of the flag types listed above and of managers who have never failed. The obtained residuals are then averaged within each of the group of flagged managers depending on the same distance from flag start.

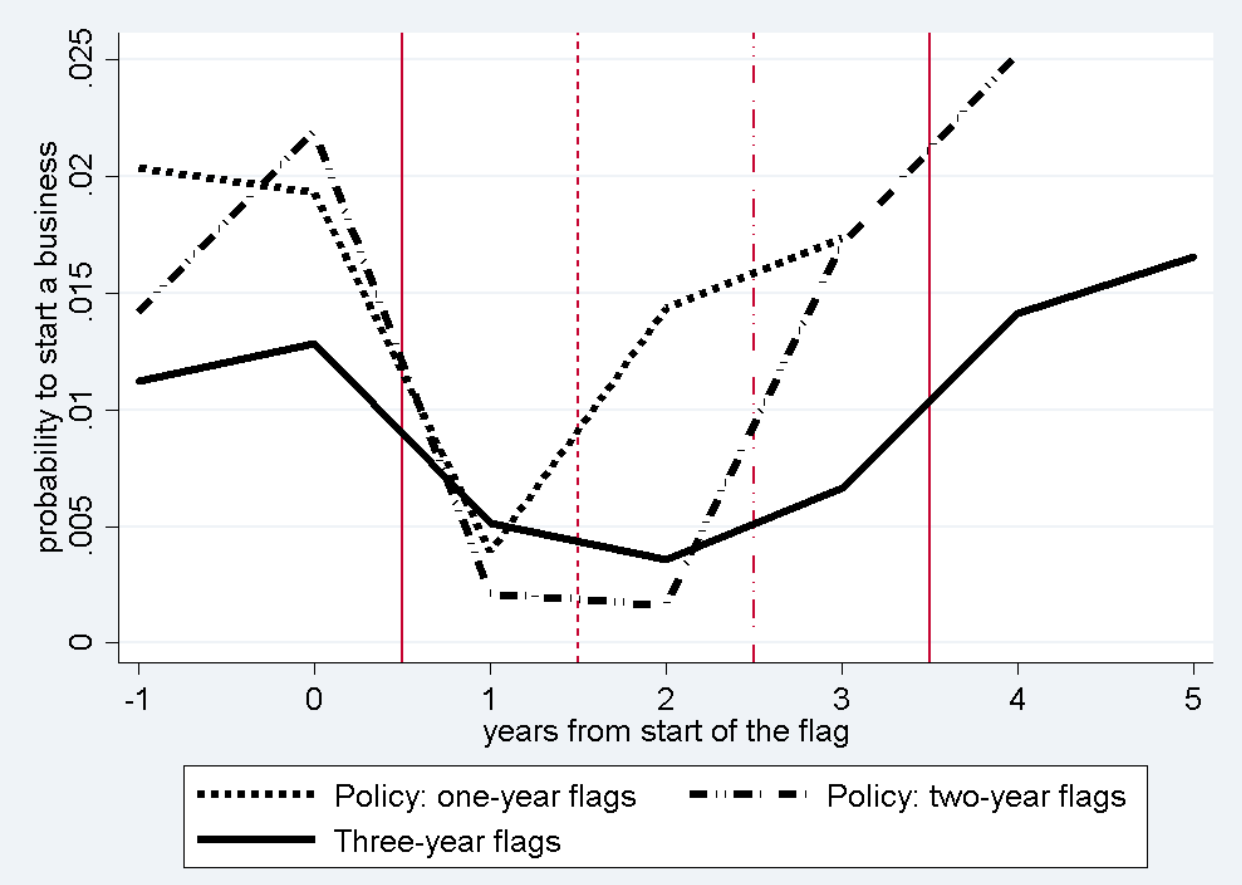


Figure 6

Average change in bank debt depending on the distance from flag and deflag

This figure plots the average residuals in the normalized change in bank debt depending on the distance from the flagging and deflagging events for a firm managed by a flagged entrepreneur. The sample is composed of firms managed by a flagged entrepreneur at the time he gets the flag. The flags considered either last three years (the standard in the old regime), or are affected by the policy change and last one year, or are affected by the policy change and last two years. The normalized change in bank debt is the difference between bank debt at year $t$ and bank debt at year $t-1$, over total assets at $t-1$. This is regressed over firm FEs and industry $\mathrm{x}$ time FEs, and the obtained residuals are averaged depending on the the distance from flag start.

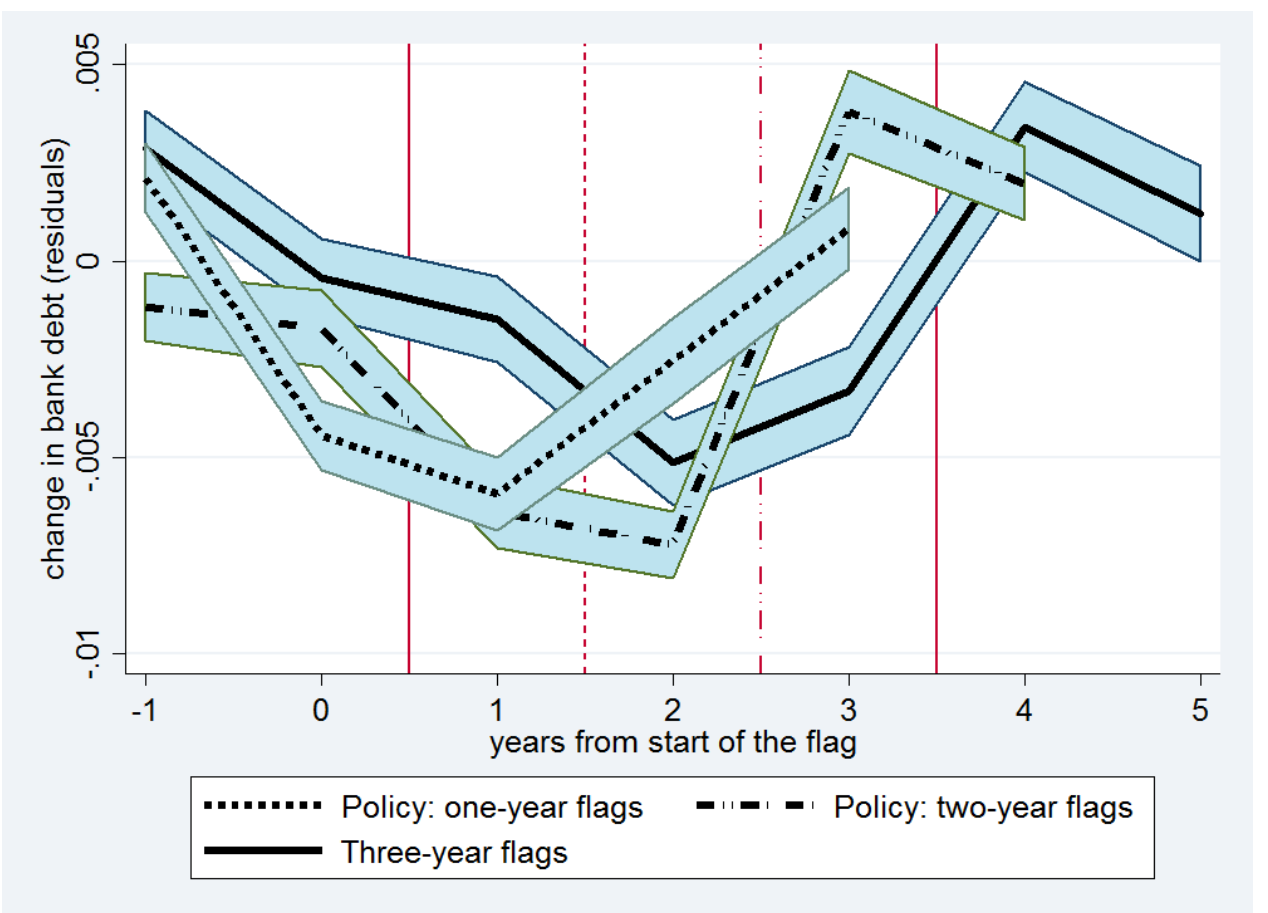




\section{Tables}

Table II

Mono-firm and multi-firm managers: summary statistics

This table reports summary statistics on the managers' population distinguishing by whether they manage one or multiple firms at the same time (respectively, 'mono-firm' and 'multi-firm' managers). We consider manager-firm relationships existing at the end of 2005 and 2015. Mention 'top 1\%' refers to the managers belonging to the $99^{\text {th }}$ percentile in the distribution of the number of firms by multi-firm managers. Sectoral concentration corresponds to the normalized Herfindhal Index in terms of the 3-digit industry classification.

\begin{tabular}{lcc}
\hline & 2005 & 2015 \\
\hline Number of managers & $3,622,469$ & $4,244,983$ \\
Share of multi-firm managers & 0.15 & 0.17 \\
Number of firms per managers (mean) & 1.23 & 2 \\
Number of firms per multi-firm man. (median) & 9 & 2 \\
Number of firms per multi-firm man. (top 1\%) & 0.24 & 9 \\
Sectoral concentration, multi-firm managers & 0.26 & 0.27 \\
Sectoral concentration, multi-firm managers (top 1\%) & 0.37 \\
\hline
\end{tabular}

Table III

Mono-firm and multi-firm managers: demographic characteristics

This table compares demographic characteristics of entrepreneurs managing one or multiple firms at the same time (respectively, 'mono-firm' and 'multi-firm' managers). The demographic variables include the age, the gender, and the place of birth. We consider manager-firm relationships existing at the end of 2005 and 2015. Stars indicate the stastistical significance of the difference between the population means: ${ }^{*} p<0.10,{ }^{* *} p<0.05,{ }^{* * *} p<0.01$.

\begin{tabular}{|c|c|c|c|c|c|c|}
\hline & \multicolumn{3}{|c|}{2005} & \multicolumn{3}{|c|}{2015} \\
\hline & Mono-firm & Multi-firm & $\Delta$ & Mono-firm & Multi-firm & $\Delta$ \\
\hline Manager's age & 46.26 & 49.24 & $\begin{array}{c}2.98^{* * *} \\
(0.016)\end{array}$ & 43.32 & 43.03 & $\begin{array}{c}-0.29^{* * *} \\
(0.016)\end{array}$ \\
\hline Manager is female & 0.284 & 0.164 & $\begin{array}{c}-0.121^{* * *} \\
(0.001)\end{array}$ & 0.284 & 0.172 & $\begin{array}{c}-0.113^{* * *} \\
(0.001)\end{array}$ \\
\hline Manager is non-French & 0.147 & 0.140 & $\begin{array}{c}-0.007^{* * *} \\
(0.001)\end{array}$ & 0.160 & 0.150 & $\begin{array}{c}-0.010^{* * *} \\
(0.000)\end{array}$ \\
\hline
\end{tabular}


Table IV

Mono-firm and multi-firm managers: summary statistics of their firms

This table compares the financial conditions of firms in which at least one manager has a mandate in another firm ('multifirm' managers) with firms in which the current managers have no other managing role elsewhere ('mono-firm' managers). We consider manager-firm relationships existing at end of 2005 and 2015. Stars indicate the stastistical significance of the difference between the population means: ${ }^{*} p<0.10,{ }^{* *} p<0.05,{ }^{* * *} p<0.01$.

\begin{tabular}{|c|c|c|c|c|c|c|}
\hline & \multicolumn{3}{|c|}{2005} & \multicolumn{3}{|c|}{2015} \\
\hline & Mono-firm & Multi-firm & $\Delta$ & Mono-firm & Multi-firm & $\Delta$ \\
\hline Sales (log) & 7.53 & 7.81 & $\begin{array}{c}0.28^{* * *} \\
(0.005)\end{array}$ & 7.51 & 7.67 & $\begin{array}{c}0.15^{* * *} \\
(0.005)\end{array}$ \\
\hline Leverage & 0.346 & 0.378 & $\begin{array}{c}0.032^{* * *} \\
(0.002)\end{array}$ & 0.295 & 0.321 & $\begin{array}{c}0.026^{* * *} \\
(0.001)\end{array}$ \\
\hline Cost of debt & 0.143 & 0.138 & $\begin{array}{c}-0.004^{*} \\
(0.002)\end{array}$ & 0.078 & 0.076 & $\begin{array}{c}-0.002^{*} \\
(0.001)\end{array}$ \\
\hline Trade credit & -0.027 & -0.029 & $\begin{array}{c}-0.002^{* * *} \\
(0.001)\end{array}$ & -0.035 & -0.046 & $\begin{array}{c}-0.011^{* * *} \\
(0.001)\end{array}$ \\
\hline Share of ST debt & 0.593 & 0.598 & $\begin{array}{c}0.005^{* * *} \\
(0.002)\end{array}$ & 0.544 & 0.555 & $\begin{array}{c}0.012^{* * *} \\
(0.002)\end{array}$ \\
\hline Return on assets & 0.120 & 0.113 & $\begin{array}{c}-0.007^{* * *} \\
(0.001)\end{array}$ & 0.108 & 0.101 & $\begin{array}{c}-0.007^{* * *} \\
(0.000)\end{array}$ \\
\hline Tangibility & 0.630 & 0.531 & $\begin{array}{c}-0.099^{* * *} \\
(0.002)\end{array}$ & 0.526 & 0.447 & $\begin{array}{c}-0.079^{* * *} \\
(0.002)\end{array}$ \\
\hline
\end{tabular}

Table V

Summary statistics of the managers' dataset

This table displays the summary statistics of the managers' dataset. The unit of observation of the panel is managerquarter. The table distinguishes by whether managers are flagged or not. Unflagged managers in this sample represent a randomly drawn $5 \%$ of the universe of unflagged managers. Flagged managers include those whose flag duration is three years (the standard in the old regime), and those affected by the policy change and whose flag duration is thus less than three years. Flagged managers are tracked from the first to the eleventh quarter after the start of the flag. "firm creation" indicates whether the manager creates at least a firm or not (in a given quarter). Other variables relates to the managers' demographics.

\begin{tabular}{lccccc}
\hline & $\mathrm{N}$ & Flagged managers & \\
& 781,050 & 0.01 & 0.10 & 0.0 & 1.0 \\
firm creation & 781,050 & 46.26 & 10.62 & 19.6 & 79.7 \\
manager's age & 781,050 & 0.19 & 0.39 & 0.0 & 1.0 \\
manager is female & 781,050 & 0.21 & 0.41 & 0.0 & 1.0 \\
manager is non-French & $\mathrm{N}$ & Unflagged managers \\
& $10,690,636$ & 0.01 & 0.08 & 0.0 & 1.0 \\
\hline firm creation & $10,690,636$ & 47.48 & 12.82 & 18.0 & 79.8 \\
manager's age & $10,690,636$ & 0.32 & 0.47 & 0.0 & 1.0 \\
manager is female & $10,690,636$ & 0.17 & 0.38 & 0.0 & 1.0 \\
manager is non-French & $10,0.0$ & Min. \\
\hline
\end{tabular}


Table VI

Summary statistics of the firms' dataset

This table displays the summary statistics of the firms' dataset. The unit of observation of the panel is firm-year. The table distinguishes by whether firms are managed by a flagged manager or not. There is maximum one flagged manager along the life of a firm. The flags considered include both those lasting three years (the standard in the old regime), and those affected by the policy change and thus lasting less than three years. The firms associated to a flagged manager are created before the start of the flag and are managed by him at the time he gets flagged. For such firms, only the first, second, and third balance sheets after the flag start are retained, and the flagged entrepreneur manages the company at any of those dates. Variables that have a name starting with " $\mathrm{D}$ " are year changes relative to lagged total assets. "D bankdebt" is thus the year change in bank debt over lagged total assets. Bank debt is decomposed into short term ("ST bankdebt") and long term ("LT bankdebt"). "Loan rate" is the interest rate paid on loans. "trade credit" is the difference between accounts payable and accounts receivable. Tangible assets are decomposed into "ground", "building", and "equip", respectively property, plant, and equipment. The year changes are taken as measures of the investment in each of those components. "Div A" indicates dividends over assets. "ROA" is the Return on Assets. "log sales" is the log of total sales, and "log tangible assets" is the log of tangible assets. Finally, "D N bank rel" indicates the year change in the number of bank relationships.

\begin{tabular}{lccccc}
\hline & $\mathrm{N}$ & Mean & St.Dev. & Min. & Max. \\
\hline D_bankdebt & 6,322 & -0.010 & 0.060 & -0.245 & 0.427 \\
D_ST_bankdebt & 6,322 & -0.003 & 0.045 & -0.223 & 0.258 \\
D_LT_bankdebt & 6,322 & -0.007 & 0.044 & -0.190 & 0.337 \\
Loan rate & 5,315 & 0.054 & 0.054 & 0.000 & 0.299 \\
D_trade_credit & 6,014 & -0.003 & 0.104 & -0.372 & 0.362 \\
D_ground & 6,322 & -0.000 & 0.001 & -0.011 & 0.022 \\
D_building & 6,322 & -0.002 & 0.012 & -0.077 & 0.177 \\
D_equip & 6,322 & -0.001 & 0.015 & -0.074 & 0.132 \\
Div_A & 6,322 & 0.025 & 0.054 & 0.000 & 0.406 \\
ROA & 6,206 & 0.092 & 0.118 & -0.428 & 0.604 \\
log_sales & 6,287 & 7.365 & 1.938 & 0.000 & 11.563 \\
log_tangible_assets & 6,290 & 4.031 & 2.131 & 0.000 & 9.879 \\
D_N_bank_rel & 5,106 & 0.080 & 0.658 & -1.000 & 4.000 \\
\hline & & & Unflagged firms & \\
& $\mathrm{N}$ & Mean & St.Dev. & Min. & Max. \\
\hline D_bankdebt & $1,372,333$ & -0.007 & 0.059 & -0.283 & 0.501 \\
D_ST_bankdebt & $1,372,333$ & -0.000 & 0.041 & -0.226 & 0.272 \\
D_LT_bankdebt & $1,372,333$ & -0.007 & 0.046 & -0.191 & 0.372 \\
Loan rate & $1,167,939$ & 0.046 & 0.047 & 0.000 & 0.300 \\
D_trade_credit & $1,315,924$ & -0.003 & 0.096 & -0.400 & 0.370 \\
D_ground & $1,372,333$ & -0.000 & 0.001 & -0.012 & 0.026 \\
D_building & $1,372,333$ & -0.001 & 0.015 & -0.082 & 0.223 \\
D_equip & $1,372,333$ & -0.001 & 0.016 & -0.075 & 0.140 \\
Div_A & $1,372,333$ & 0.035 & 0.063 & 0.000 & 0.435 \\
ROA & $1,356,118$ & 0.115 & 0.114 & -0.476 & 0.608 \\
log_sales & $1,354,965$ & 7.475 & 1.902 & 0.000 & 11.720 \\
log_tangible_assets & $1,359,124$ & 4.220 & 2.130 & 0.000 & 9.917 \\
D_N_bank_rel & $1,107,236$ & 0.085 & 0.607 & -1.000 & 4.000 \\
\hline
\end{tabular}


Table VII

Entrepreneurs' probability to start a business

This table analyzes the quarterly probability to start a business for an entrepreneur. This is a function of whether he is a flagged manager, of whether he has been deflagged, of demographic controls, and time fixed effects. In the first two columns, the sample is composed of a randomly drawn $5 \%$ of the universe of unflagged managers, and of all flagged managers whose flag duration is three years (the standard in the old regime). Those flagged managers are tracked from the nineth to the fourteenth quarters after flag start. Identification of the deflag effect is achieved comparing the dynamics of the restarting probability before and after deflag. In the second two columns, we add to the previous sample policy-affected managers, whose flag duration is thus less than three years. We track both groups of flagged managers from the first to the eleventh quarter after flag start. Policy-affect managers get deflagged over this period, while old regime managers do not. The distance-from-flag-start dummies capture the average dynamics taken after flag start. The differential relative to that dynamics taken after deflag by policy-affected managers corresponds to the deflag effect. Parameters are estimated using a Probit model. The estimates refer to marginal effects setting the variables to their median or to zero in the case of dummy variables. The conditional probability of failure is obtained setting the explanatory variables to their median, except the dummies which are set to zero. Standard errors are clustered at the manager level, and t-statistics are in parenthesis. Statistical significance: ${ }^{*} p<0.10,{ }^{* *} p<0.05,{ }^{* * *} p<0.01$.

\begin{tabular}{|c|c|c|c|c|}
\hline \multicolumn{5}{|l|}{ Depedent Variable: } \\
\hline & $\begin{array}{c}(1) \\
\text { firm creation }\end{array}$ & $\begin{array}{c}(2) \\
\text { firm creation }\end{array}$ & $\begin{array}{c}(3) \\
\text { firm creation }\end{array}$ & $\begin{array}{c}(4) \\
\text { firm creation }\end{array}$ \\
\hline manager has been deflagged & $\begin{array}{c}0.0011^{* * *} \\
(4.09)\end{array}$ & $\begin{array}{c}0.0011^{* * *} \\
(3.97)\end{array}$ & $\begin{array}{c}0.0015^{* * *} \\
(7.63)\end{array}$ & $\begin{array}{c}0.0010^{* * *} \\
(4.99)\end{array}$ \\
\hline flagged manager & $\begin{array}{c}0.0024^{* * *} \\
(12.32)\end{array}$ & $\begin{array}{c}0.0020^{* * *} \\
(10.13)\end{array}$ & & \\
\hline 1 quarter since flag start & & & $\begin{array}{c}0.0036^{* * *} \\
(14.37)\end{array}$ & $\begin{array}{c}0.0030^{* * *} \\
(11.94)\end{array}$ \\
\hline 2 quarters since flag start & & & $\begin{array}{c}0.0021^{* * *} \\
(7.85)\end{array}$ & $\begin{array}{l}0.0015^{* * *} \\
(5.68)\end{array}$ \\
\hline 3 quarters since flag start & & & $\begin{array}{c}0.0016^{* * *} \\
(5.93)\end{array}$ & $\begin{array}{c}0.0011^{* * *} \\
(3.81)\end{array}$ \\
\hline 4 quarters since flag start & & & $\begin{array}{c}0.0014^{* * *} \\
(4.90)\end{array}$ & $\begin{array}{c}0.0008^{* * *} \\
(2.87)\end{array}$ \\
\hline 5 quarters since flag start & & & $\begin{array}{c}0.0023^{* * *} \\
(8.52)\end{array}$ & $\begin{array}{l}0.0017^{* * *} \\
\quad(6.48)\end{array}$ \\
\hline 6 quarters since flag start & & & $\begin{array}{l}0.0021^{* * *} \\
\quad(7.87)\end{array}$ & $\begin{array}{c}0.0016^{* * *} \\
(5.93)\end{array}$ \\
\hline 7 quarters since flag start & & & $\begin{array}{l}0.0021^{* * *} \\
\quad(7.71)\end{array}$ & $\begin{array}{l}0.0015^{* * *} \\
\quad(5.67)\end{array}$ \\
\hline 8 quarters since flag start & & & $\begin{array}{c}0.0019^{* * *} \\
\quad(7.04)\end{array}$ & $\begin{array}{c}0.0014^{* * *} \\
\quad(5.11)\end{array}$ \\
\hline 9 quarters since flag start & & & $\begin{array}{c}0.0020^{* * *} \\
(7.53)\end{array}$ & $\begin{array}{c}0.0015^{* * *} \\
\quad(5.68)\end{array}$ \\
\hline 10 quarters since flag start & & & $\begin{array}{c}0.0024^{* * *} \\
(9.05)\end{array}$ & $\begin{array}{l}0.0020^{* * *} \\
\quad(7.32)\end{array}$ \\
\hline 11 quarters since flag start & & & $\begin{array}{c}0.0026^{* * *} \\
\quad(9.46)\end{array}$ & $\begin{array}{l}0.0021^{* * *} \\
\quad(7.80)\end{array}$ \\
\hline manager's age & & $\begin{array}{c}-0.0003^{* * *} \\
(-140.55)\end{array}$ & & $\begin{array}{c}-0.0003^{* * *} \\
(-139.58)\end{array}$ \\
\hline manager is female & & $\begin{array}{c}-0.0025^{* * *} \\
(-39.55)\end{array}$ & & $\begin{array}{c}-0.0026^{* * *} \\
(-40.85)\end{array}$ \\
\hline manager is non-French & & $\begin{array}{c}0.0014^{* * *} \\
(23.39)\end{array}$ & & $\begin{array}{c}0.0014^{* * *} \\
(23.10)\end{array}$ \\
\hline Conditional proba. (at median) & 0.0067 & 0.0065 & 0.0067 & 0.0066 \\
\hline Time FE & Yes & Yes & Yes & Yes \\
\hline Observation & $10,943,602$ & $10,943,602$ & $11,471,686$ & $11,471,686$ \\
\hline
\end{tabular}




\section{Table VIII}

New firms: productivity at restart

This table focuses on new firms' productivity at creation. The sample includes firms created by unflagged managers, by flagged managers whose flag duration is three years (the standard in the old regime), and by policy-affected managers whose flag duration is thus less than three years. Independent variables capture whether, at the creation, the manager is flagged or has been deflagged. As a consequence, the parameters' estimates capture the difference relative to unflagged managers. The table also reports the difference between the two parameters' estimates, and tests if this is different from zero. Standard errors are clustered at the year level, and t-statistics are in parenthesis. Statistical significance: ${ }^{*} p<0.10$, ** $p<0.05,{ }^{* * *} p<0.01$.

\begin{tabular}{lcccc}
\hline Depedent Variable: & & & & \\
& $(1)$ & $(2)$ & $(3)$ & $(4)$ \\
& ROA & ROA & EBITDA/sales & EBITDA/sales \\
\hline manager is flagged at creation & $-0.017^{*}$ & $-0.021^{* *}$ & $-0.142^{* * *}$ & $-0.129^{* * *}$ \\
& $(-1.90)$ & $(-2.82)$ & $(-4.51)$ & $(-3.65)$ \\
manager is deflagged at creation & $-0.007^{*}$ & $-0.010^{* *}$ & -0.030 & -0.022 \\
& $(-1.90)$ & $(-2.94)$ & $(-1.04)$ & $(-0.70)$ \\
& & & & \\
log(total assets) & -0.005 & -0.004 & $0.054^{* * *}$ & $0.031^{* * *}$ \\
& $(-0.85)$ & $(-0.74)$ & $(10.80)$ & $(5.15)$ \\
\hline Param. difference & -0.009 & -0.011 & -0.112 & -0.108 \\
t-statistic & -1.20 & -1.44 & -2.17 & -1.98 \\
\hline Year FE & Yes & Yes & Yes & Yes \\
Industry FE & No & Yes & No & Yes \\
Observation & 73,923 & 72,932 & 60,834 & 60,115 \\
$R^{2}$ & 0.008 & 0.014 & 0.009 & 0.094 \\
\hline
\end{tabular}

\section{Table IX}

\section{New firms: productivity after six years from creation}

This table focuses on new firms' productivity after six years from creation. The sample includes firms created by unflagged managers, by flagged managers whose flag duration is three years (the standard in the old regime), and by policy-affected managers whose flag duration is thus less than three years. Independent variables capture whether, at the creation, the manager is flagged or has been deflagged. As a consequence, the parameters' estimates capture the difference relative to unflagged managers. The table also reports the difference between the two parameters' estimates, and tests if this is different from zero. Standard errors are clustered at the year level, and t-statistics are in parenthesis. Statistical significance: ${ }^{*} p<0.10,{ }^{* *} p<0.05,{ }^{* * *} p<0.01$.

\begin{tabular}{|c|c|c|c|c|}
\hline \multicolumn{5}{|l|}{ Depedent Variable: } \\
\hline & (1) & $(2)$ & (3) & (4) \\
\hline & ROA & ROA & EBITDA/sales & EBITDA/sales \\
\hline manager is flagged at creation & $\begin{array}{l}-0.034 \\
(-1.77)\end{array}$ & $\begin{array}{l}-0.032 \\
(-1.72)\end{array}$ & $\begin{array}{l}-0.009 \\
(-0.21)\end{array}$ & $\begin{array}{l}-0.031 \\
(-0.66)\end{array}$ \\
\hline manager is deflagged at creation & $\begin{array}{l}-0.044 \\
(-1.15)\end{array}$ & $\begin{array}{l}-0.046 \\
(-1.32)\end{array}$ & $\begin{array}{l}-0.012 \\
(-0.14)\end{array}$ & $\begin{array}{l}-0.028 \\
(-0.47)\end{array}$ \\
\hline $\log$ (total assets) & $\begin{array}{l}-0.001 \\
(-0.18)\end{array}$ & $\begin{array}{l}0.001 \\
(0.22)\end{array}$ & $\begin{array}{c}0.070^{* * *} \\
(7.66)\end{array}$ & $\begin{array}{c}0.059^{* * *} \\
(5.83)\end{array}$ \\
\hline Param. difference & 0.010 & 0.015 & 0.003 & -0.003 \\
\hline t-statistic & 0.22 & 0.33 & 0.03 & -0.05 \\
\hline Year FE & Yes & Yes & Yes & Yes \\
\hline Industry $\mathrm{FE}$ & No & Yes & No & Yes \\
\hline Observation & 6,165 & 6,094 & 5,725 & 5,665 \\
\hline$R^{2}$ & 0.012 & 0.025 & 0.029 & 0.111 \\
\hline
\end{tabular}




\section{Table X}

\section{New firms: probability of failure}

This table analyzes new firms' quarterly probability of failure. The sample is composed of a randomly drawn $15 \%$ of the universe of firms created between 2005 and 2015. The flags considered are of any type and do not include only those lasting three years or those affected by the policy change. Otherwise, by construction, we would focus only on flagged managers who do not fail again, thus biasing the estimation. Firms are tracked until the fifth year from the date of creation. Failure in a quarter is function of whether the manager is currently flagged and of distance-from-initial-failure dummies. The parameters are estimated using a Probit model. Parameters' estimates refer to marginal effects setting firms' age to the median, and the flag and the distance-from-initial-failure dummies to zero. The conditional probability of failure is obtained setting firms' age to the median, and the flag and the distance-from-initial-failure dummies to zero. Standard errors are clustered at the firm level, and t-statistics are in parenthesis. Statistical significance: $* p<0.10, * *$ $p<0.05, * * * p<0.01$.

\begin{tabular}{|c|c|c|c|c|}
\hline \multicolumn{5}{|l|}{ Depedent Variable: } \\
\hline & $(1)$ & $(2)$ & $(3)$ & $(4)$ \\
\hline & fail next quarter & fail in $1 y r$ & have bad event & have bad event or fail \\
\hline manager is currently flagged & $\begin{array}{c}0.00365^{* * *} \\
(7.04)\end{array}$ & $\begin{array}{l}0.00439^{* * *} \\
(8.25)\end{array}$ & $\begin{array}{c}0.00072^{* *} \\
(2.30)\end{array}$ & $\begin{array}{c}0.00361^{* * *} \\
(5.50)\end{array}$ \\
\hline 1 yr since manager's initial failure & $\begin{array}{l}0.00566^{* * *} \\
\quad(11.06)\end{array}$ & $\begin{array}{l}0.00541^{* * *} \\
\quad(10.25)\end{array}$ & $\begin{array}{l}0.00271^{* * *} \\
\quad(8.92)\end{array}$ & $\begin{array}{l}0.00793^{* * *} \\
\quad(12.30)\end{array}$ \\
\hline 2 yrs since manager's initial failure & $\begin{array}{l}0.00262^{* * *} \\
\quad(4.30)\end{array}$ & $\begin{array}{l}0.00212^{* * *} \\
\quad(3.37)\end{array}$ & $\begin{array}{l}0.00125^{* * *} \\
\quad(3.55)\end{array}$ & $\begin{array}{l}0.00401^{* * *} \\
\quad(5.44)\end{array}$ \\
\hline 3 yrs since manager's initial failure & $\begin{array}{l}0.00220^{* * *} \\
\quad(3.25)\end{array}$ & $\begin{array}{l}0.00197^{* * *} \\
\quad(2.84)\end{array}$ & $\begin{array}{c}0.00072^{*} \\
\quad(1.83)\end{array}$ & $\begin{array}{l}0.00262^{* * *} \\
\quad(3.21)\end{array}$ \\
\hline 4 yrs since manager's initial failure & $\begin{array}{l}0.00379^{* * *} \\
\quad(6.65)\end{array}$ & $\begin{array}{l}0.00382^{* * *} \\
\quad(6.49)\end{array}$ & $\begin{array}{l}0.00119^{* * *} \\
\quad(3.65)\end{array}$ & $\begin{array}{l}0.00453^{* * *} \\
\quad(6.66)\end{array}$ \\
\hline 5 yrs since manager's initial failure & $\begin{array}{l}0.00416^{* * *} \\
\quad(6.87)\end{array}$ & $\begin{array}{l}0.00464^{* * *} \\
\quad(7.67)\end{array}$ & $\begin{array}{l}0.00108^{* * *} \\
\quad(3.03)\end{array}$ & $\begin{array}{l}0.00457^{* * *} \\
\quad(6.40)\end{array}$ \\
\hline firm's age & $\begin{array}{l}0.00075^{* * *} \\
\quad(28.44)\end{array}$ & $\begin{array}{l}0.00078^{* * * *} \\
\quad(28.56)\end{array}$ & $\begin{array}{l}0.00071^{* * *} \\
\quad(37.18)\end{array}$ & $\begin{array}{l}0.00136^{* * *} \\
\quad(40.04)\end{array}$ \\
\hline Condit. proba. of failure (at median) & 0.00540 & 0.00574 & 0.00156 & 0.00645 \\
\hline Industry x Quarter FE & Yes & Yes & Yes & Yes \\
\hline Observation & $3,006,367$ & $3,007,713$ & $2,927,615$ & $3,023,452$ \\
\hline
\end{tabular}


Table XI

Existing firms: funding sources as a function of deflag. Identification by 3-year discontinuity This table shows the effect of the manager being deflagged on existing firms' debt components and loan rate, obtained exploiting the three-year discontinuity in the flag. The sample is composed of firms with no flagged manager, and firms with an old regime flagged manager who manages the firm at the time he gets the flag. Flags have thus a duration of three years. Firms with flagged managers are tracked from two years before to two years after the manager gets deflagged. Dependent variables are defined in the summary statistics. The "manager has been deflagged" dummy identifies the difference in the dynamics before and after the three-year discontinuity. Standard errors are clustered at the year level, and t-statistics are in parenthesis. Statistical significance: ${ }^{*} p<0.10,{ }^{* *} p<0.05,{ }^{* *} p<0.01$.

\begin{tabular}{|c|c|c|c|c|c|}
\hline \multicolumn{6}{|l|}{ Depedent Variable: } \\
\hline & (1) & $(2)$ & $(3)$ & (4) & $(5)$ \\
\hline & D_bankdebt & D_ST_bankdebt & D_LT_bankdebt & Loan rate & D_trade_credit \\
\hline \multirow[t]{2}{*}{ manager has been deflagged } & $0.007^{* * *}$ & $0.004^{* * *}$ & $0.003^{* *}$ & $-0.003^{* *}$ & -0.001 \\
\hline & $(3.67)$ & $(2.80)$ & $(2.32)$ & $(-1.98)$ & $(-0.28)$ \\
\hline Firm FE & Yes & Yes & Yes & Yes & Yes \\
\hline 3 digit industry $\mathrm{x}$ Year FE & Yes & Yes & Yes & Yes & Yes \\
\hline Observation & $1,391,469$ & $1,391,469$ & $1,391,469$ & $1,002,549$ & $1,331,943$ \\
\hline$R^{2}$ & 0.233 & 0.130 & 0.268 & 0.553 & 0.124 \\
\hline
\end{tabular}

Table XII

Existing firms: employment of funds as a function of deflag. Identification by 3-year discontinuity This table shows the effect of the manager being deflagged on existing firms' asset components and dividends paid, obtained exploiting the three-year discontinuity in the flag. The sample is composed of firms with no flagged manager, and firms with an old regime flagged manager who manages the firm at the time he gets the flag. Flags have thus a duration of three years. Firms with flagged managers are tracked from two years before to two years after the manager gets deflagged. Dependent variables are defined in the summary statistics. The "manager has been deflagged" dummy identifies the difference in the dynamics before and after the three-year discontinuity. Standard errors are clustered at the year level, and t-statistics are in parenthesis. Statistical significance: ${ }^{*} p<0.10,{ }^{* *} p<0.05,{ }^{* * *} p<0.01$.

\begin{tabular}{lcccc}
\hline Depedent Variable: & & & & \\
\hline & $(1)$ & $(2)$ & $(3)$ & $(4)$ \\
& D_ground & D_building & D_equip & Div_A \\
\hline manager has been deflagged & -0.000 & $0.001^{* * *}$ & -0.000 & -0.000 \\
& $(-0.11)$ & $(2.72)$ & $(-0.44)$ & $(-0.29)$ \\
\hline Firm FE & Yes & Yes & Yes & Yes \\
3 digit industry x Year FE & Yes & Yes & Yes & Yes \\
Observation & $1,391,469$ & $1,391,469$ & $1,391,469$ & $1,391,469$ \\
$R^{2}$ & 0.281 & 0.303 & 0.219 & 0.619 \\
\hline
\end{tabular}




\section{Table XIII}

Existing firms: funding sources as a function of deflag. Identification by policy shock

This table shows the effect of the manager being deflagged on existing firms' debt components and loan rate, obtained exploiting the policy shock. The sample is composed of firms with no flagged manager, and firms with a flagged manager who manages the firm at the time he gets the flag. Flagged managers are either old regime or policy-affected. The first are flagged for three years, while the latter have a flag duration of less than three years. Firms with flagged managers are tracked from the first to the third balance sheet after the flag start. Dependent variables are defined in the summary statistics. The dynamics taken after the flag start is captured by the two dummies "2 yrs since manager's flag start" and "3 yrs since manager's flag start". Since policy-affected flagged managers get deflagged between the first and the third year after flag start, the "manager has been deflagged" dummy is identified comparing the dynamics of their firms with the dynamics of firms managed by old regime flagged managers (while controlling for the distance from flag start). Standard errors are clustered at the year level, and t-statistics are in parenthesis. Statistical significance: ${ }^{*} p<0.10,{ }^{* *}$ $p<0.05,{ }^{* * *} p<0.01$.

\begin{tabular}{|c|c|c|c|c|c|}
\hline \multicolumn{6}{|l|}{ Depedent Variable: } \\
\hline & (1) & $(2)$ & $(3)$ & $(4)$ & $(5)$ \\
\hline & D_bankdebt & D_ST_bankdebt & D_LT_bankdebt & Loan rate & D_trade_credit \\
\hline manager has been deflagged & $\begin{array}{c}0.008^{* *} \\
(2.83)\end{array}$ & $\begin{array}{r}0.004^{*} \\
(2.03)\end{array}$ & $\begin{array}{l}0.004 \\
(1.65)\end{array}$ & $\begin{array}{c}-0.004^{*} \\
(-1.91)\end{array}$ & $\begin{array}{c}-0.008^{*} \\
(-2.00)\end{array}$ \\
\hline 2 yrs since manager's flag start & $\begin{array}{l}-0.002 \\
(-1.27)\end{array}$ & $\begin{array}{l}0.001 \\
(0.80)\end{array}$ & $\begin{array}{c}-0.003^{* *} \\
(-2.79)\end{array}$ & $\begin{array}{l}0.001 \\
(0.49)\end{array}$ & $\begin{array}{l}0.008^{*} \\
(2.00)\end{array}$ \\
\hline 3 yrs since manager's flag start & $\begin{array}{l}-0.001 \\
(-0.25)\end{array}$ & $\begin{array}{l}-0.000 \\
(-0.03) \\
\end{array}$ & $\begin{array}{l}-0.000 \\
(-0.34) \\
\end{array}$ & $\begin{array}{l}0.002 \\
(0.89) \\
\end{array}$ & $\begin{array}{c}0.008^{*} \\
(2.16) \\
\end{array}$ \\
\hline Firm FE & Yes & Yes & Yes & Yes & Yes \\
\hline 3 digit industry $\mathrm{x}$ Year FE & Yes & Yes & Yes & Yes & Yes \\
\hline Observation & $1,392,120$ & $1,392,120$ & $1,392,120$ & $1,002,913$ & $1,332,502$ \\
\hline$R^{2}$ & 0.234 & 0.131 & 0.268 & 0.553 & 0.124 \\
\hline
\end{tabular}

Table XIV

Existing firms: employment of funds as a function of deflag. Identification by policy shock This table shows the effect of the manager being deflagged on existing firms' asset components and dividends paid, obtained exploiting the policy shock. The sample is composed of firms with no flagged manager, and firms with a flagged manager who manages the firm at the time he gets the flag. Flagged managers are either old regime or policy-affected. The first are flagged for three years, while the latter have a flag duration of less than three years. Firms with flagged managers are tracked from the first to the third balance sheet after the flag start. Dependent variables are defined in the summary statistics. The dynamics taken after the flag start is captured by the two dummies " 2 yrs since manager's flag start" and "3 yrs since manager's flag start". Since policy-affected flagged managers get deflagged between the first and the third year after flag start, the "manager has been deflagged" dummy is identified comparing the dynamics of their firms with the dynamics of firms managed by old regime flagged managers (while controlling for the distance from flag start). Standard errors are clustered at the year level, and t-statistics are in parenthesis. Statistical significance: * $p<0.10,{ }^{* *} p<0.05,{ }^{* * *} p<0.01$.

\begin{tabular}{lcccc}
\hline Depedent Variable: & \multicolumn{3}{c}{} \\
\hline & $(1)$ & $(2)$ & $(3)$ & $(4)$ \\
& D_ground & D_building & D_equip & Div_A \\
\hline manager has been deflagged & 0.000 & $0.001^{* *}$ & 0.001 & $0.003^{*}$ \\
& $(1.36)$ & $(3.00)$ & $(1.08)$ & $(1.96)$ \\
& & & & \\
2 yrs since manager's flag start & $-0.000^{*}$ & 0.000 & -0.000 & -0.000 \\
& $(-2.26)$ & $(0.35)$ & $(-0.04)$ & $(-0.12)$ \\
3 yrs since manager's flag start & -0.000 & -0.000 & 0.001 & -0.000 \\
& $(-0.68)$ & $(-0.43)$ & $(1.69)$ & $(-0.34)$ \\
\hline Firm FE & Yes & Yes & Yes & Yes \\
3 digit industry x Year FE & Yes & Yes & Yes & Yes \\
Observation & $1,392,120$ & $1,392,120$ & $1,392,120$ & $1,392,120$ \\
$R^{2}$ & 0.282 & 0.303 & 0.220 & 0.619 \\
\hline
\end{tabular}


Table XV

Existing firms: funding sources as a function of deflag. Differentiating by industry volatility This table shows the effect of the manager being deflagged on existing firms' debt components and loan rate, differentiating by industry volatility. The sample is composed of firms with no flagged manager, and firms with a flagged manager who manages the firm at the time he gets the flag. Flagged managers are either old regime or policy-affected. The first are flagged for three years, while the latter have a flag duration of less than three years. Firms with flagged managers are tracked from the first to the third balance sheet after the flag start. The identification of the "manager has been deflagged" dummy is achieved exploiting the policy shock, as in Table XIII. The effect of the manager being deflagged is differentiated depending on the Return on Assets volatility of the industry. This is obtained first regressing the Return on Assets of every firm over year FEs. We compute the standard deviation of the obtained residuals within each firm. We average it across firms of the same 3 digit industry, and split the industries in terciles. "firm's industry has high ROA TS st.dev." thus indicates if the firm's industry is in the top tercile for that ROA time series standard deviation statistic. Statistical significance: ${ }^{*} p<0.10,{ }^{* *} p<0.05,{ }^{* * *} p<0.01$

\begin{tabular}{|c|c|c|c|c|c|}
\hline \multicolumn{6}{|l|}{ Depedent Variable: } \\
\hline & (1) & $(2)$ & (3) & (4) & (5) \\
\hline & D_bankdebt & D_ST_bankdebt & D_LT_bankdebt & Loan rate & D_trade_credit \\
\hline manager has been deflagged & $\begin{array}{c}0.006 \\
(1.67)\end{array}$ & $\begin{array}{c}0.003 \\
(1.39)\end{array}$ & $\begin{array}{c}0.002 \\
(0.77)\end{array}$ & $\begin{array}{l}-0.004 \\
(-1.40)\end{array}$ & $\begin{array}{l}-0.002 \\
(-0.51)\end{array}$ \\
\hline — $\mathrm{x}$ firm's industry has high ROA TS st.dev. & $\begin{array}{c}0.015^{* *} \\
(2.79)\end{array}$ & $\begin{array}{l}0.004 \\
(0.68)\end{array}$ & $\begin{array}{l}0.011 \\
(1.81)\end{array}$ & $\begin{array}{l}-0.005 \\
(-1.08)\end{array}$ & $\begin{array}{c}-0.043^{* * *} \\
(-4.15)\end{array}$ \\
\hline 2 yrs since manager's flag start & $\begin{array}{l}-0.002 \\
(-0.87)\end{array}$ & $\begin{array}{l}0.002 \\
(0.76)\end{array}$ & $\begin{array}{c}-0.004^{* *} \\
(-2.34)\end{array}$ & $\begin{array}{l}0.002 \\
(1.05)\end{array}$ & $\begin{array}{l}0.005 \\
(1.49)\end{array}$ \\
\hline 3 yrs since manager's flag start & $\begin{array}{l}0.000 \\
(0.04)\end{array}$ & $\begin{array}{l}0.000 \\
(0.15)\end{array}$ & $\begin{array}{l}-0.000 \\
(-0.14)\end{array}$ & $\begin{array}{l}0.002 \\
(0.86)\end{array}$ & $\begin{array}{l}0.003 \\
(0.84)\end{array}$ \\
\hline Other dist. from flag start interac. & Yes & Yes & Yes & Yes & Yes \\
\hline Firm FE & Yes & Yes & Yes & Yes & Yes \\
\hline 3 digit industry $\mathrm{x}$ Year $\mathrm{FE}$ & Yes & Yes & Yes & Yes & Yes \\
\hline Observation & $1,392,120$ & $1,392,120$ & $1,392,120$ & $1,002,913$ & $1,332,502$ \\
\hline$R^{2}$ & 0.234 & 0.131 & 0.268 & 0.553 & 0.124 \\
\hline
\end{tabular}


Table XVI

Existing firms: funding sources as a function of deflag. Differentiating by probability of failure of the industry This table shows the effect of the manager being deflagged on existing firms' debt components and loan rate, differentiating by probability of failure of the industry. The sample is composed of firms with no flagged manager, and firms with a flagged manager who manages the firm at the time he gets the flag. Flagged managers are either old regime or policy-affected. The first are flagged for three years, while the latter have a flag duration of less than three years. Firms with flagged managers are tracked from the first to the third balance sheet after the flag start. The identification of the "manager has been deflagged" dummy is achieved exploiting the policy shock, as in Table XIII. The effect of the manager being deflagged is differentiated depending on the probability of failure of the firm's industry. This is obtained first regressing a dummy capturing failure over year and 3-digit industry FEs for the universe of firms. We compute the distribution of the obtained 3-digit industry FEs, and split the industries in terciles. "firm's industry is risky" thus indicates if the firm's industry is in the top tercile of that distribution. Statistical significance: ${ }^{*} p<0.10,{ }^{* *} p<0.05,{ }^{* * *} p<0.01$

\begin{tabular}{|c|c|c|c|c|c|}
\hline \multicolumn{6}{|l|}{ Depedent Variable: } \\
\hline & $(1)$ & $\stackrel{(2)}{ }$ & (3) & (4) & $\begin{array}{l}\text { (5) } \\
\text { P trade }\end{array}$ \\
\hline & D_bankdebt & D_ST_bankdebt & D_LT_bankdebt & Loan rate & D_trade_credit \\
\hline manager has been deflagged & $\begin{array}{l}0.005 \\
(1.83)\end{array}$ & $\begin{array}{l}-0.001 \\
(-0.51)\end{array}$ & $\begin{array}{c}0.006^{*} \\
(2.00)\end{array}$ & $\begin{array}{l}-0.003 \\
(-1.76)\end{array}$ & $\begin{array}{c}-0.012^{* *} \\
(-3.06)\end{array}$ \\
\hline - $\mathrm{x}$ firm's industry is risky & $\begin{array}{l}0.009^{*} \\
(1.97)\end{array}$ & $\begin{array}{c}0.014^{* * *} \\
(8.66)\end{array}$ & $\begin{array}{l}-0.005 \\
(-1.14)\end{array}$ & $\begin{array}{l}-0.005 \\
(-1.35)\end{array}$ & $\begin{array}{l}0.011 \\
(1.23)\end{array}$ \\
\hline 2 yrs since manager's flag start & $\begin{array}{l}-0.002 \\
(-1.07)\end{array}$ & $\begin{array}{l}0.001 \\
(1.01)\end{array}$ & $\begin{array}{l}-0.004 \\
(-1.73)\end{array}$ & $\begin{array}{l}0.002 \\
(1.35)\end{array}$ & $\begin{array}{l}0.002 \\
(0.55)\end{array}$ \\
\hline 3 yrs since manager's flag start & $\begin{array}{l}-0.003 \\
(-0.96)\end{array}$ & $\begin{array}{l}-0.001 \\
(-0.35)\end{array}$ & $\begin{array}{l}-0.002 \\
(-0.94)\end{array}$ & $\begin{array}{l}0.003 \\
(1.79)\end{array}$ & $\begin{array}{c}0.006^{*} \\
(1.96)\end{array}$ \\
\hline Other dist. from flag start interac. & Yes & Yes & Yes & Yes & Yes \\
\hline Firm FE & Yes & Yes & Yes & Yes & Yes \\
\hline 3 digit industry $\mathrm{x}$ Year $\mathrm{FE}$ & Yes & Yes & Yes & Yes & Yes \\
\hline Observation & $1,337,906$ & $1,337,906$ & $1,337,906$ & 962,775 & $1,280,707$ \\
\hline$R^{2}$ & 0.234 & 0.129 & 0.269 & 0.553 & 0.123 \\
\hline
\end{tabular}


Table XVII

Existing firms: funding sources as a function of deflag. Differentiating by manager FE volatility This table shows the effect of the manager being deflagged on existing firms' debt components and loan rate, differentiating by manager fixed effect volatility. The sample is composed of firms with no flagged manager, and firms with a flagged manager who manages the firm at the time he gets the flag. Flagged managers are either old regime or policy-affected. The first are flagged for three years, while the latter have a flag duration of less than three years. Firms with flagged managers are tracked from the first to the third balance sheet after the flag start. The identification of the "manager has been deflaged" dumy is achie exped is differentiated on Assets of every fir over industry $x$ year FEs, frm FEs, and manager FEs. We compute the standard deviation of the estimated manager FEs within each 3 digit industry, and split the industries in terciles. "firm's industry has high manage FE st.dev." thus indicates if the firm's industry is in the top tercile for that manager FE standard deviation statistic Standard errors are clustered at the year level, and t-statistics are in parenthesis. Statistical significance: ${ }^{*} p<0.10$, $^{* *}$ $p<0.05, * * * p<0.01$

\begin{tabular}{|c|c|c|c|c|c|}
\hline \multicolumn{6}{|l|}{ Depedent Variable: } \\
\hline & (1) & $(2)$ & (3) & (4) & (5) \\
\hline & D_bankdebt & D_ST_bankdebt & D_LT_bankdebt & Loan rate & D_trade_credit \\
\hline \multirow[t]{2}{*}{ manager has been deflagged } & 0.005 & 0.002 & 0.003 & -0.002 & -0.004 \\
\hline & (1.19) & $(0.68)$ & $(1.24)$ & $(-0.95)$ & $(-0.90)$ \\
\hline \multirow{2}{*}{ — x firm's industry has high manager FE st.dev. } & 0.008 & $0.006^{* *}$ & 0.001 & $-0.006^{*}$ & -0.011 \\
\hline & & & $(0.45)$ & $(-1.86)$ & $(-1.22)$ \\
\hline \multirow[t]{2}{*}{2 yrs since manager's flag start } & -0.004 & 0.001 & $-0.005^{* *}$ & 0.001 & 0.005 \\
\hline & $(-1.71)$ & $(0.65)$ & $(-2.94)$ & $(0.37)$ & $(1.27)$ \\
\hline \multirow[t]{2}{*}{3 yrs since manager's flag start } & -0.002 & 0.000 & -0.002 & -0.002 & 0.005 \\
\hline & $(-0.84)$ & $(0.12)$ & $(-1.05)$ & $(-0.91)$ & $(1.15)$ \\
\hline Other dist. from flag start interac. & Yes & Yes & Yes & Yes & Yes \\
\hline Firm FE & Yes & Yes & Yes & Yes & Yes \\
\hline 3 digit industry $x$ Year FE & Yes & Yes & Yes & Yes & Yes \\
\hline Observation & $1,392,120$ & $1,392,120$ & $1,392,120$ & $1,002,913$ & $1,332,502$ \\
\hline$R^{2}$ & 0.234 & 0.131 & 0.268 & 0.553 & 0.124 \\
\hline
\end{tabular}




\section{Table XVIII}

Existing firms: change in the number of bank relationships

This table shows the effect of the manager being deflagged on existing firms' number of bank relationships. The sample is composed of firms with no flagged manager, and firms with a flagged manager who manages the firm at the time he gets the flag. Flagged managers are either old regime or policy-affected. The first are flagged for three years, while the latter have a flag duration of less than three years. Firms with flagged managers are tracked from the first to the third balance sheet after the flag start. The dependent variable is the yearly change in the number of bank relationships. The identification of the "manager has been deflagged" dummy is achieved exploiting the policy shock, as in Table XIII. The effect of the manager being deflagged is differentiated depending on the firm's size, the firm's tangible assets ratio, the

\begin{tabular}{|c|c|c|c|c|c|c|}
\hline \multicolumn{7}{|l|}{ Depedent Variable: } \\
\hline & $\stackrel{(1)}{D}$ & $\stackrel{(2)}{D}$ N bank rel & $\begin{array}{c}(3) \\
\mathrm{D} N \text { bank rel }\end{array}$ & $\stackrel{(4)}{\mathrm{D}}$ & $\begin{array}{c}(5) \\
\text { D N bank rel }\end{array}$ & $\begin{array}{c}(6) \\
\text { D N bank rel }\end{array}$ \\
\hline manager has been deflagged & $\begin{array}{c}0.124^{* * *} \\
(3.68)\end{array}$ & $\begin{array}{c}0.123^{* * *} \\
(3.57)\end{array}$ & $\begin{array}{c}0.082^{*} \\
(1.92)\end{array}$ & $\begin{array}{c}0.147^{* * *} \\
(3.36)\end{array}$ & $\begin{array}{c}0.142^{* * *} \\
(4.56)\end{array}$ & $\begin{array}{c}0.130^{* *} \\
(2.55)\end{array}$ \\
\hline$-\mathrm{x}$ firm is large & & & $\begin{array}{l}0.094 \\
(1.40)\end{array}$ & & & \\
\hline - $\mathrm{x}$ firm has low tangible assets ratio & & & & $\begin{array}{l}-0.067 \\
(-0.86)\end{array}$ & & \\
\hline — $\mathrm{x}$ firm's industry has high ROA TS st.dev. & & & & & $\begin{array}{l}-0.115 \\
(-1.37)\end{array}$ & \\
\hline — $\mathrm{x}$ firm's industry has high manager FE st.dev. & & & & & & $\begin{array}{l}-0.015 \\
(-0.26)\end{array}$ \\
\hline 2 yrs since manager's flag start & $\begin{array}{l}-0.023 \\
(-0.78)\end{array}$ & $\begin{array}{l}-0.024 \\
(-0.81)\end{array}$ & $\begin{array}{l}-0.016 \\
(-0.45)\end{array}$ & $\begin{array}{l}-0.034 \\
(-0.94)\end{array}$ & $\begin{array}{l}-0.021 \\
(-0.83)\end{array}$ & $\begin{array}{l}-0.028 \\
(-0.98)\end{array}$ \\
\hline 3 yrs since manager's flag start & $\begin{array}{r}-0.053^{*} \\
(-2.24)\end{array}$ & $\begin{array}{c}-0.056^{* *} \\
(-2.38)\end{array}$ & $\begin{array}{l}0.000 \\
(0.00)\end{array}$ & $\begin{array}{l}-0.070 \\
(-1.82)\end{array}$ & $\begin{array}{c}-0.068^{* *} \\
(-2.52)\end{array}$ & $\begin{array}{c}-0.086^{* *} \\
(-2.54)\end{array}$ \\
\hline firm has low tangible assets ratio & & & & $\begin{array}{c}-0.044^{* * *} \\
(-12.36) \\
\end{array}$ & & \\
\hline Other dist. from flag start interac. & - & - & Yes & Yes & Yes & Yes \\
\hline Firm FE & Yes & Yes & Yes & Yes & Yes & Yes \\
\hline 3 digit industry $x$ Year $\mathrm{FE}$ & Yes & Yes & Yes & Yes & Yes & Yes \\
\hline Rating FE & No & Yes & No & No & No & No \\
\hline Observation & $1,110,493$ & $1,110,472$ & $1,110,493$ & $1,110,493$ & $1,110,493$ & $1,110,493$ \\
\hline$R^{2}$ & 0.193 & 0.194 & 0.193 & 0.193 & 0.193 & 0.193 \\
\hline
\end{tabular}




\section{Appendix}

Table XIX

New firms: financial conditions at restart

This table focuses on new firms' financial conditions at creation. The sample includes firms created by unflagged managers, by flagged managers whose flag duration is three years (the standard in the old regime), and by policy-affected managers whose flag duration is thus less than three years. Independent variables capture whether, at the creation, the manager is flagged or has been deflagged. As a consequence, the parameters' estimates capture the difference relative to unflagged managers. The table also reports the difference between the two parameters' estimates, which corresponds to the stigma effect, and tests if this is different from zero. Standard errors are clustered at the year level, and t-statistics are in parenthesis. Statistical significance: ${ }^{*} p<0.10,{ }^{* *} p<0.05,{ }^{* * *} p<0.01$.

\begin{tabular}{|c|c|c|c|c|c|c|}
\hline \multicolumn{7}{|l|}{ Depedent Variable: } \\
\hline & $(1)$ & $(2)$ & $(3)$ & (4) & $(5)$ & $(6)$ \\
\hline & Bankdebt/assets & Bankdebt/assets & Loan rate & Loan rate & Trade credit & Trade credit \\
\hline manager is flagged at creation & $\begin{array}{c}-0.101^{* * *} \\
(-8.59)\end{array}$ & $\begin{array}{c}-0.086^{* * *} \\
(-6.12)\end{array}$ & $\begin{array}{c}0.008^{*} \\
(2.19)\end{array}$ & $\begin{array}{c}0.008^{*} \\
(2.03)\end{array}$ & $\begin{array}{l}0.007 \\
(0.34)\end{array}$ & $\begin{array}{l}0.027 \\
(1.74)\end{array}$ \\
\hline manager is deflagged at creation & $\begin{array}{c}-0.060^{* * *} \\
(-3.17)\end{array}$ & $\begin{array}{c}-0.052^{* *} \\
(-2.39)\end{array}$ & $\begin{array}{l}0.004 \\
(1.54)\end{array}$ & $\begin{array}{l}0.004 \\
(1.28)\end{array}$ & $\begin{array}{l}-0.020 \\
(-1.41)\end{array}$ & $\begin{array}{l}-0.010 \\
(-0.64)\end{array}$ \\
\hline $\log ($ total assets $)$ & $\begin{array}{c}0.019^{* * *} \\
(15.02)\end{array}$ & $\begin{array}{c}0.019^{* * *} \\
(15.82)\end{array}$ & $\begin{array}{c}-0.003^{* * *} \\
(-8.27)\end{array}$ & $\begin{array}{c}-0.003^{* * *} \\
(-8.37)\end{array}$ & $\begin{array}{c}-0.006^{* * *} \\
(-3.28)\end{array}$ & $\begin{array}{l}-0.001 \\
(-0.51)\end{array}$ \\
\hline Param. difference: stigma effect & -0.041 & -0.034 & 0.004 & 0.004 & 0.027 & 0.037 \\
\hline t-statistic & -1.96 & -1.31 & 0.68 & 0.74 & 1.27 & 1.86 \\
\hline Year FE & Yes & Yes & Yes & Yes & Yes & Yes \\
\hline Industry FE & No & Yes & No & Yes & No & Yes \\
\hline Observation & 73,923 & 72,932 & 54,849 & 54,116 & 73,923 & 72,932 \\
\hline$R^{2}$ & 0.031 & 0.102 & 0.042 & 0.054 & 0.002 & 0.197 \\
\hline
\end{tabular}

Table XX

New firms: financial conditions after six years from creation

This table focuses on new firms' financial conditions after six years from creation. The sample includes firms created by unflagged managers, by flagged managers whose flag duration is three years (the standard in the old regime), and by policy-affected managers whose flag duration is thus less than three years. Independent variables capture whether, at the creation, the manager is flagged or has been deflagged. As a consequence, the parameters' estimates capture the difference relative to unflagged managers. The table also reports the difference between the two parameters' estimates, which corresponds to the stigma effect, and tests if this is different from zero. Standard errors are clustered at the year level, and t-statistics are in parenthesis. Statistical significance: ${ }^{*} p<0.10,{ }^{* *} p<0.05, * * * p<0.01$.

\begin{tabular}{|c|c|c|c|c|c|c|}
\hline \multicolumn{7}{|l|}{ Depedent Variable: } \\
\hline & $(1)$ & $(2)$ & (3) & (4) & $(5)$ & $(6)$ \\
\hline & Bankdebt/assets & Bankdebt/assets & Loan rate & Loan rate & Trade credit & Trade credit \\
\hline \multirow[t]{2}{*}{ manager is flagged at creation } & 0.004 & 0.008 & 0.003 & 0.004 & $0.039^{* *}$ & $0.040^{* *}$ \\
\hline & $(0.29)$ & $(0.52)$ & $(0.74)$ & $(0.97)$ & $(2.89)$ & $(2.76)$ \\
\hline \multirow{2}{*}{ manager is deflagged at creation } & $0.060^{* * *}$ & $0.056^{* * *}$ & $0.022^{* * *}$ & $0.022^{* * *}$ & $0.078^{*}$ & 0.081 \\
\hline & $(6.19)$ & $(5.16)$ & $(5.58)$ & $(5.78)$ & $(2.27)$ & $(1.66)$ \\
\hline \multirow[t]{2}{*}{$\log ($ total assets $)$} & $0.017^{* * *}$ & $0.018^{* * *}$ & $-0.007^{* * *}$ & $-0.007^{* * *}$ & $-0.011^{* *}$ & -0.006 \\
\hline & $(5.13)$ & $(5.61)$ & $(-14.16)$ & $(-10.75)$ & $(-2.51)$ & $(-1.08)$ \\
\hline \multirow{2}{*}{$\begin{array}{l}\text { Param. difference: stigma effect } \\
\text { t-statistic }\end{array}$} & -0.056 & -0.048 & -0.019 & -0.018 & -0.038 & -0.041 \\
\hline & -2.76 & -2.31 & -3.86 & -3.68 & -1.13 & -0.90 \\
\hline Year FE & Yes & Yes & Yes & Yes & Yes & Yes \\
\hline Industry FE & No & Yes & $\mathrm{No}$ & Yes & No & Yes \\
\hline Observation & 6,165 & 6,094 & 4,186 & 4,136 & 6,165 & 6,094 \\
\hline$R^{2}$ & 0.032 & 0.084 & 0.041 & 0.052 & 0.009 & 0.178 \\
\hline
\end{tabular}


Table XXI

Existing firms: employment of funds as a function of deflag. Differentiating by industry volatility

This table shows the effect of the manager being deflagged on existing firms' asset components and dividends paid, differentiating by industry volatility. The sample is composed of firms with no flagged manager, and firms with a flagged manager who manages the firm at the time he gets the flag. Flagged managers are either old regime or policy-affected. The first are flagged for three years, while the latter have a flag duration of less than three years. Firms with flagged managers are tracked from the first to the third balance sheet after the flag start. The identification of the "manager has been deflagged" dummy is achieved exploiting the policy shock, as in Table XIII The effect of the manager being deflagged is differentiated depending on the Return on Assets volatility of the industry. This is obtained first regressing the Return on Assets of every firm over year FEs. We compute the standard deviation of the obtained residuals within each firm. We average it across firms of the same 3 digit industry, and split the industries in terciles. "firm's industry has high ROA TS st.dev." thus indicates if the firm's industry is in the top tercile for that ROA time series standard deviation statistic. Statistical significance: ${ }^{*} p<0.10,{ }^{* *} p<0.05, * * * p<0.01$.

\begin{tabular}{|c|c|c|c|c|}
\hline \multicolumn{5}{|l|}{ Depedent Variable: } \\
\hline & $\begin{array}{c}(1) \\
\text { D_ground }\end{array}$ & $\begin{array}{c}(2) \\
\text { D_building }\end{array}$ & $\begin{array}{c}(3) \\
\text { D_equip }\end{array}$ & $\begin{array}{c}(4) \\
\text { Div_A }\end{array}$ \\
\hline manager has been deflagged & $\begin{array}{l}0.000 \\
(1.74)\end{array}$ & $\begin{array}{c}0.001^{* *} \\
(2.92)\end{array}$ & $\begin{array}{l}0.001 \\
(1.02)\end{array}$ & $\begin{array}{l}0.003 \\
(1.42)\end{array}$ \\
\hline — x firm's industry has high ROA TS st.dev. & $\begin{array}{c}-0.000^{* *} \\
(-3.02)\end{array}$ & $\begin{array}{l}-0.001 \\
(-1.65)\end{array}$ & $\begin{array}{l}0.001 \\
(0.71)\end{array}$ & $\begin{array}{l}0.003 \\
(0.89)\end{array}$ \\
\hline 2 yrs since manager's flag start & $\begin{array}{l}-0.000 \\
(-1.33)\end{array}$ & $\begin{array}{l}0.000 \\
(0.21)\end{array}$ & $\begin{array}{l}-0.000 \\
(-0.01)\end{array}$ & $\begin{array}{l}0.000 \\
(0.79)\end{array}$ \\
\hline 3 yrs since manager's flag start & $\begin{array}{l}-0.000 \\
(-0.46)\end{array}$ & $\begin{array}{l}-0.000 \\
(-0.28)\end{array}$ & $\begin{array}{c}0.001^{*} \\
(1.89)\end{array}$ & $\begin{array}{l}-0.000 \\
(-0.12)\end{array}$ \\
\hline Other dist. from flag start interac. & Yes & Yes & Yes & Yes \\
\hline Firm FE & Yes & Yes & Yes & Yes \\
\hline 3 digit industry $\mathrm{x}$ Year FE & Yes & Yes & Yes & Yes \\
\hline Observation & $1,392,120$ & $1,392,120$ & $1,392,120$ & $1,392,120$ \\
\hline$R^{2}$ & 0.282 & 0.303 & 0.220 & 0.619 \\
\hline
\end{tabular}


Table XXII

Existing firms: employment of funds as a function of deflag.

Differentiating by probability of failure of the industry

This table shows the effect of the manager being deflagged on existing firms' asset components and dividends paid, differentiating by industry volatility. The sample is composed of firms with no flagged manager, and firms with a flagged manager who manages the firm at the time he gets the flag. Flagged managers are either old regime or policy-affected. The first are flagged for three years, while the latter have a flag duration of less than three years. Firms with flagged managers are tracked from the first to the third balance sheet after the flag start. The identification of the "manager has been deflagged" dummy is achieved exploiting the policy shock, as in Table XIII The effect of the manager being deflagged is differentiated depending on the probability of failure of the firm's industry. This is obtained first regressing a dummy capturing failure over year and 3-digit industry FEs for the universe of firms. We compute the distribution of the obtained 3-digit industry FEs, and split the industries in terciles. "firm's industry is risky" thus indicates if the firm's industry is in the top tercile of that distribution. Statistical significance: ${ }^{*} p<0.10,{ }^{* *} p<0.05, * * * p<0.01$.

\begin{tabular}{|c|c|c|c|c|}
\hline \multicolumn{5}{|l|}{ Depedent Variable: } \\
\hline & $\begin{array}{c}(1) \\
\text { D_ground }\end{array}$ & $\begin{array}{c}(2) \\
\text { D_building }\end{array}$ & $\begin{array}{c}(3) \\
\text { D_equip }\end{array}$ & $\begin{array}{c}(4) \\
\text { Div_A }\end{array}$ \\
\hline manager has been deflagged & $\begin{array}{c}0.000^{*} \\
(1.94)\end{array}$ & $\begin{array}{c}0.001^{* *} \\
(2.46)\end{array}$ & $\begin{array}{l}0.000 \\
(0.40)\end{array}$ & $\begin{array}{c}0.004^{* *} \\
(2.39)\end{array}$ \\
\hline$-\mathrm{x}$ firm's industry is risky & $\begin{array}{l}-0.000 \\
(-1.71)\end{array}$ & $\begin{array}{l}-0.000 \\
(-0.83)\end{array}$ & $\begin{array}{c}0.001 \\
(0.64)\end{array}$ & $\begin{array}{l}-0.002 \\
(-1.56)\end{array}$ \\
\hline 2 yrs since manager's flag start & $\begin{array}{c}-0.000^{* *} \\
(-2.77)\end{array}$ & $\begin{array}{l}0.000 \\
(0.81)\end{array}$ & $\begin{array}{l}-0.000 \\
(-0.49)\end{array}$ & $\begin{array}{c}0.001 \\
(0.69)\end{array}$ \\
\hline 3 yrs since manager's flag start & $\begin{array}{l}-0.000 \\
(-0.58)\end{array}$ & $\begin{array}{l}-0.000 \\
(-0.12)\end{array}$ & $\begin{array}{c}0.001 \\
(0.93) \\
\end{array}$ & $\begin{array}{l}-0.002 \\
(-1.21)\end{array}$ \\
\hline Other dist. from flag start interac. & Yes & Yes & Yes & Yes \\
\hline Firm FE & Yes & Yes & Yes & Yes \\
\hline 3 digit industry $\mathrm{x}$ Year FE & Yes & Yes & Yes & Yes \\
\hline Observation & $1,337,906$ & $1,337,906$ & $1,337,906$ & $1,337,906$ \\
\hline$R^{2}$ & 0.280 & 0.301 & 0.218 & 0.620 \\
\hline
\end{tabular}


Table XXIII

Existing firms: employment of funds as a function of deflag.

Differentiating by manager FE volatility

This table shows the effect of the manager being deflagged on existing firms' asset components and dividends paid, differentiating by manager fixed effect volatility. The sample is composed of firms with no flagged manager, and firms with a flagged manager who manages the firm at the time he gets the flag. Flagged managers are either old regime or policy-affected. The first are flagged for three years, while the latter have a flag duration of less than three years. Firms with flagged managers are tracked from the first to the third balance sheet after the flag start. The identification of the "manager has been deflagged" dummy is achieved exploiting the policy shock, as in Table XIII The effect of the manager being deflagged is differentiated depending on the manager fixed effects volatility of the industry. This is obtained first regressing the Return on Assets of every firm over industry x year FEs, firm FEs, and manager FEs. We compute the standard deviation of the estimated manager FEs within each 3 digit industry, and split the industries in terciles. "firm's industry has high manager FE st.dev." thus indicates if the firm's industry is in the top tercile for that manager FE standard deviation statistic. Standard errors are clustered at the year level, and t-statistics are in parenthesis. Statistical significance: ${ }^{*} p<0.10, * * p<0.05, * * * p<0.01$.

\begin{tabular}{|c|c|c|c|c|}
\hline \multicolumn{5}{|l|}{ Depedent Variable: } \\
\hline & $(1)$ & $(2)$ & $(3)$ & $(4)$ \\
\hline & D_ground & D_building & D_equip & Div_A \\
\hline \multirow[t]{2}{*}{ manager has been deflagged } & $0.000^{*}$ & $0.001^{* *}$ & 0.000 & 0.004 \\
\hline & $(1.85)$ & $(3.17)$ & $(0.69)$ & $(1.32)$ \\
\hline \multirow{2}{*}{ — $\mathrm{x}$ firm's industry has high manager FE st.dev. } & -0.000 & $-0.001^{*}$ & 0.001 & -0.002 \\
\hline & $(-1.29)$ & $(-2.16)$ & $(0.31)$ & $(-0.48)$ \\
\hline \multirow[t]{2}{*}{2 yrs since manager's flag start } & $-0.000^{*}$ & -0.000 & -0.000 & 0.000 \\
\hline & $(-1.95)$ & $(-0.26)$ & $(-0.86)$ & $(0.76)$ \\
\hline \multirow[t]{2}{*}{3 yrs since manager's flag start } & -0.000 & -0.000 & 0.001 & 0.002 \\
\hline & $(-0.99)$ & $(-0.42)$ & $(1.17)$ & $(1.40)$ \\
\hline Other dist. from flag start interac. & Yes & Yes & Yes & Yes \\
\hline Firm FE & Yes & Yes & Yes & Yes \\
\hline 3 digit industry $\mathrm{x}$ Year FE & Yes & Yes & Yes & Yes \\
\hline Observation & $1,392,120$ & $1,392,120$ & $1,392,120$ & $1,392,120$ \\
\hline$R^{2}$ & 0.282 & 0.303 & 0.220 & 0.619 \\
\hline
\end{tabular}




\section{Table XXIV}

Existing firms: funding sources as a function of deflag.

\section{Adding rating FEs}

This table shows the effect of the manager being deflagged on existing firms' debt components and loan rate, differentiating by manager fixed effect volatility. The sample is composed of firms with no flagged manager, and firms with a flagged manager who manages the firm at the time he gets the flag. Flagged managers are either old regime or policy-affected. The first are flagged for three years, while the latter have a flag duration of less than three years. Firms with flagged managers are tracked from the first to the third balance sheet after the flag start. The identification of the "manager has been deflagged" dummy is achieved exploiting the policy shock, as in Table XIII Relative to that identification, we add rating FEs as controls. Standard errors are clustered at the year level, and t-statistics are in parenthesis. Statistical significance: $* p<0.10, * * p<0.05, * * * p<0.01$.

\begin{tabular}{|c|c|c|c|c|c|}
\hline \multicolumn{6}{|l|}{ Depedent Variable: } \\
\hline & (1) & $(2)$ & $(3)$ & (4) & $(5)$ \\
\hline & D_bankdebt & D_ST_bankdebt & D_LT_bankdebt & Loan rate & D_trade_credit \\
\hline manager has been deflagged & $\begin{array}{c}0.008^{* *} \\
(2.82)\end{array}$ & $\begin{array}{c}0.004^{*} \\
(1.93)\end{array}$ & $\begin{array}{l}0.004 \\
(1.70)\end{array}$ & $\begin{array}{c}-0.004^{*} \\
(-1.87)\end{array}$ & $\begin{array}{c}-0.008^{*} \\
(-1.98)\end{array}$ \\
\hline 2 yrs since manager's flag start & $\begin{array}{l}-0.002 \\
(-1.39)\end{array}$ & $\begin{array}{l}0.001 \\
(0.72)\end{array}$ & $\begin{array}{c}-0.003^{* *} \\
(-2.77)\end{array}$ & $\begin{array}{l}0.001 \\
(0.45)\end{array}$ & $\begin{array}{l}0.008^{*} \\
(2.02)\end{array}$ \\
\hline 3 yrs since manager's flag start & $\begin{array}{l}-0.001 \\
(-0.69)\end{array}$ & $\begin{array}{l}-0.001 \\
(-0.40)\end{array}$ & $\begin{array}{l}-0.001 \\
(-0.55)\end{array}$ & $\begin{array}{l}0.002 \\
(0.92)\end{array}$ & $\begin{array}{c}0.008^{*} \\
(2.07)\end{array}$ \\
\hline Firm FE & Yes & Yes & Yes & Yes & Yes \\
\hline 3 digit industry $\mathrm{x}$ Year FE & Yes & Yes & Yes & Yes & Yes \\
\hline Rating FE & Yes & Yes & Yes & Yes & Yes \\
\hline Observation & $1,392,076$ & $1,392,076$ & $1,392,076$ & $1,002,894$ & $1,332,465$ \\
\hline$R^{2}$ & 0.242 & 0.136 & 0.271 & 0.554 & 0.125 \\
\hline
\end{tabular}

\section{Table XXV}

Existing firms: employment of funds as a function of deflag.

\section{Adding rating FEs}

This table shows the effect of the manager being deflagged on existing firms' asset components and dividends paid, differentiating by manager fixed effect volatility. The sample is composed of firms with no flagged manager, and firms with a flagged manager who manages the firm at the time he gets the flag. Flagged managers are either old regime or policy-affected. The first are flagged for three years, while the latter have a flag duration of less than three years. Firms with flagged managers are tracked from the first to the third balance sheet after the flag start. The identification of the "manager has been deflagged" dummy is achieved exploiting the policy shock, as in Table XIII Relative to that identification, we add rating FEs as controls. Standard errors are clustered at the year level, and t-statistics are in parenthesis. Statistical significance: ${ }^{*} p<0.10$, ** $p<0.05, * * * p<0.01$.

\begin{tabular}{lcccc}
\hline Depedent Variable: & \multicolumn{3}{c}{} \\
& $(1)$ & $(2)$ & $(3)$ & $(4)$ \\
& D_ground & D_building & D_equip & Div_A \\
\hline manager has been deflagged & 0.000 & $0.001^{* *}$ & 0.001 & $0.003^{*}$ \\
& $(1.35)$ & $(2.92)$ & $(1.10)$ & $(2.16)$ \\
& & & & \\
2 yrs since manager's flag start & $-0.000^{* *}$ & 0.000 & -0.000 & -0.000 \\
& $(-2.27)$ & $(0.31)$ & $(-0.09)$ & $(-0.17)$ \\
3 yrs since manager's flag start & -0.000 & -0.000 & 0.001 & -0.001 \\
& $(-0.71)$ & $(-0.55)$ & $(1.52)$ & $(-0.79)$ \\
\hline Firm FE & Yes & Yes & Yes & Yes \\
3 digit industry x Year FE & Yes & Yes & Yes & Yes \\
Rating FE & Yes & Yes & Yes & Yes \\
Observation & $1,392,076$ & $1,392,076$ & $1,392,076$ & $1,392,076$ \\
$R^{2}$ & 0.282 & 0.304 & 0.221 & 0.631 \\
\hline
\end{tabular}


Table XXVI

Existing firms: funding sources as a function of deflag.

Adding rating FEs and other controls

This table shows the effect of the manager being deflagged on existing firms' debt components and loan rate, differentiating by manager fixed effect volatility. The sample is composed of firms with no flagged manager, and firms with a flagged manager who manages the firm at the time he gets the flag. Flagged managers are either old regime or policy-affected. The first are flagged for three years, while the latter have a flag duration of less than three years. Firms with flagged managers are tracked from the first to the third balance sheet after the flag start. The identification of the "manager has been deflagged" dummy is achieved exploiting the policy shock, as in Table XIII Relative to that identification, we add rating FEs, Return On Assets, log of sales, and log of tangible assets as controls. Standard errors are clustered at the year level, and t-statistics are in parenthesis. Statistical significance: ${ }^{*} p<0.10,{ }^{* *} p<0.05,{ }^{* * *} p<0.01$.

\begin{tabular}{|c|c|c|c|c|c|}
\hline \multicolumn{6}{|l|}{ Depedent Variable: } \\
\hline & $\begin{array}{c}(1) \\
\text { D_bankdebt }\end{array}$ & $\begin{array}{c}(2) \\
\text { D_ST_bankdebt }\end{array}$ & $\begin{array}{c}(3) \\
\text { D_LT_bankdebt }\end{array}$ & $\begin{array}{c}\text { (4) } \\
\text { Loan rate }\end{array}$ & $\begin{array}{c}(5) \\
\text { D_trade_credit }\end{array}$ \\
\hline manager has been deflagged & $\begin{array}{c}0.008^{* *} \\
(2.88)\end{array}$ & $\begin{array}{c}0.005^{*} \\
(1.85)\end{array}$ & $\begin{array}{l}0.004 \\
(1.53)\end{array}$ & $\begin{array}{l}-0.004 \\
(-1.71)\end{array}$ & $\begin{array}{r}-0.009^{*} \\
(-2.13)\end{array}$ \\
\hline 2 yrs since manager's flag start & $\begin{array}{l}-0.001 \\
(-0.74)\end{array}$ & $\begin{array}{l}0.002 \\
(1.29)\end{array}$ & $\begin{array}{c}-0.003^{* *} \\
(-2.36)\end{array}$ & $\begin{array}{l}0.001 \\
(0.50)\end{array}$ & $\begin{array}{c}0.009^{* *} \\
(2.40)\end{array}$ \\
\hline 3 yrs since manager's flag start & $\begin{array}{l}-0.000 \\
(-0.01)\end{array}$ & $\begin{array}{l}0.000 \\
(0.13)\end{array}$ & $\begin{array}{l}-0.000 \\
(-0.15)\end{array}$ & $\begin{array}{l}0.002 \\
(0.81)\end{array}$ & $\begin{array}{c}0.010^{* *} \\
(2.72)\end{array}$ \\
\hline ROA & $\begin{array}{c}-0.077^{* * *} \\
(-23.16)\end{array}$ & $\begin{array}{c}-0.046^{* * *} \\
(-21.33)\end{array}$ & $\begin{array}{c}-0.031^{* * *} \\
(-23.67)\end{array}$ & $\begin{array}{c}0.022^{* * *} \\
(17.53)\end{array}$ & $\begin{array}{c}-0.167^{* * *} \\
(-44.28)\end{array}$ \\
\hline log_sales & $\begin{array}{c}-0.001^{* * *} \\
(-6.86)\end{array}$ & $\begin{array}{c}-0.000^{* *} \\
(-3.01)\end{array}$ & $\begin{array}{c}-0.001^{* * *} \\
(-4.12)\end{array}$ & $\begin{array}{c}0.003^{* * *} \\
(16.44)\end{array}$ & $\begin{array}{c}-0.004^{* * *} \\
(-11.72)\end{array}$ \\
\hline log_tangible_assets & $\begin{array}{c}0.007^{* * *} \\
(6.57)\end{array}$ & $\begin{array}{c}0.003^{* * *} \\
(8.89)\end{array}$ & $\begin{array}{c}0.004^{* * *} \\
(5.32)\end{array}$ & $\begin{array}{c}-0.005^{* * *} \\
(-25.30)\end{array}$ & $\begin{array}{c}0.001^{* * *} \\
(10.06)\end{array}$ \\
\hline Firm FE & Yes & Yes & Yes & Yes & Yes \\
\hline 3 digit industry $\mathrm{x}$ Year FE & Yes & Yes & Yes & Yes & Yes \\
\hline Rating FE & Yes & Yes & Yes & Yes & Yes \\
\hline Observation & $1,350,212$ & $1,350,212$ & $1,350,212$ & 974,780 & $1,294,174$ \\
\hline$R^{2}$ & 0.255 & 0.145 & 0.276 & 0.562 & 0.139 \\
\hline
\end{tabular}


Table XXVII

Existing firms: employment of funds as a function of deflag.

\section{Adding rating FEs and other controls}

This table shows the effect of the manager being deflagged on existing firms' asset components and dividends paid, differentiating by manager fixed effect volatility. The sample is composed of firms with no flagged manager, and firms with a flagged manager who manages the firm at the time he gets the flag. Flagged managers are either old regime or policy-affected. The first are flagged for three years, while the latter have a flag duration of less than three years. Firms with flagged managers are tracked from the first to the third balance sheet after the flag start. The identification of the "manager has been deflagged" dummy is achieved exploiting the policy shock, as in Table XIII Relative to that identification, we add rating FEs, Return On Assets, log of sales, and log of tangible assets as controls. Standard errors are clustered at the year level, and t-statistics are in parenthesis. Statistical significance: $* p<0.10, * * p<0.05, * * *$ $p<0.01$.

\begin{tabular}{|c|c|c|c|c|}
\hline \multicolumn{5}{|l|}{ Depedent Variable: } \\
\hline & (1) & $(2)$ & (3) & $(4)$ \\
\hline & D_ground & D_building & D_equip & Div_A \\
\hline \multirow[t]{2}{*}{ manager has been deflagged } & 0.000 & $0.001^{* *}$ & 0.001 & $0.003^{*}$ \\
\hline & $(1.46)$ & $(2.50)$ & $(0.90)$ & $(2.03)$ \\
\hline \multirow[t]{2}{*}{2 yrs since manager's flag start } & $-0.000^{*}$ & 0.000 & -0.000 & -0.001 \\
\hline & $(-2.16)$ & $(1.24)$ & $(-0.15)$ & $(-1.24)$ \\
\hline \multirow[t]{2}{*}{3 yrs since manager's flag start } & -0.000 & 0.000 & 0.001 & -0.002 \\
\hline & $(-0.58)$ & $(0.10)$ & $(1.64)$ & $(-1.50)$ \\
\hline \multirow[t]{2}{*}{ ROA } & 0.000 & $-0.003^{* * *}$ & -0.000 & $0.084^{* * *}$ \\
\hline & $(1.34)$ & $(-7.17)$ & $(-1.10)$ & $(10.25)$ \\
\hline \multirow[t]{2}{*}{ log_sales } & 0.000 & $-0.000^{* * *}$ & $-0.000^{* * *}$ & $-0.001^{* * *}$ \\
\hline & $(0.89)$ & $(-5.04)$ & $(-9.99)$ & $(-5.74)$ \\
\hline \multirow[t]{2}{*}{ log_tangible_assets } & $0.000^{*}$ & $0.001^{* *}$ & $0.002^{* * *}$ & $-0.001^{* * *}$ \\
\hline & $(2.06)$ & $(3.17)$ & $(6.70)$ & $(-8.58)$ \\
\hline Firm FE & Yes & Yes & Yes & Yes \\
\hline 3 digit industry $\mathrm{x}$ Year FE & Yes & Yes & Yes & Yes \\
\hline Rating FE & Yes & Yes & Yes & Yes \\
\hline Observation & $1,350,212$ & $1,350,212$ & $1,350,212$ & $1,350,212$ \\
\hline$R^{2}$ & 0.277 & 0.304 & 0.224 & 0.632 \\
\hline
\end{tabular}

